\title{
Influence of temperature on the molecular composition of ions and charged clusters during pure biogenic nucleation
}

Carla Frege $^{1}$, Ismael K. Ortega ${ }^{2}$, Matti P. Rissanen ${ }^{3}$, Arnaud P. Praplan ${ }^{3}$, Gerhard Steiner ${ }^{3,4,5}$, Martin Heinritzi ${ }^{6}$, Lauri Ahonen $^{3}$, António Amorim ${ }^{7}$, Anne-Kathrin Bernhammer ${ }^{4,18}$, Federico Bianchi ${ }^{1,3}$, Sophia Brilke ${ }^{4,5,6}$, Martin Breitenlechner ${ }^{4, a}$, Lubna Dada ${ }^{3}$, António Dias ${ }^{7}$, Jonathan Duplissy ${ }^{3,8}$, Sebastian Ehrhart ${ }^{8, b}$, Imad El-Haddad ${ }^{1}$, Lukas Fischer ${ }^{4}$, Claudia Fuchs ${ }^{1}$, Olga Garmash ${ }^{3}$, Marc Gonin ${ }^{9}$, Armin Hansel ${ }^{4,18}$, Christopher R. Hoyle ${ }^{1}$, Tuija Jokinen ${ }^{3}$, Heikki Junninen ${ }^{3,17}$, Jasper Kirkby ${ }^{6,8}$, Andreas Kürten ${ }^{6}$, Katrianne Lehtipalo ${ }^{1,3}$, Markus Leiminger ${ }^{4,6}$, Roy Lee Mauldin ${ }^{3,16}$, Ugo Molteni ${ }^{1}$, Leonid Nichman ${ }^{10}$, Tuukka Petäjää, Nina Sarnela ${ }^{3}$, Siegfried Schobesberger ${ }^{3,14}$, Mario Simon ${ }^{6}$, Mikko Sipilä ${ }^{3}$, Dominik Stolzenburg ${ }^{5}$, António Tomé ${ }^{11}$, Alexander L. Vogel ${ }^{1,8}$, Andrea C. Wagner ${ }^{6}$, Robert Wagner ${ }^{3}$, Mao Xiao ${ }^{1}$, Chao Yan $^{3}$, Penglin Ye ${ }^{12,15}$, Joachim Curtius $^{4}$, Neil M. Donahue ${ }^{12}$, Richard C. Flagan ${ }^{13}$, Markku Kulmala ${ }^{3}$, Douglas R. Worsnop ${ }^{3,14,15}$, Paul M. Winkler ${ }^{5}$, Josef Dommen ${ }^{1}$, and Urs Baltensperger ${ }^{1}$

${ }^{1}$ Paul Scherrer Institute, Laboratory of Atmospheric Chemistry, 5232 Villigen, Switzerland

${ }^{2}$ ONERA - The French Aerospace Lab, 91123 Palaiseau, France

${ }^{3}$ University of Helsinki, Department of Physics, P.O. Box 64, University of Helsinki, 00014 Helsinki, Finland

${ }^{4}$ University of Innsbruck, Institute of Ion Physics and Applied Physics, Technikerstraße 25, 6020 Innsbruck, Austria

${ }^{5}$ University of Vienna, Faculty of Physics, Boltzmanngasse 5, 1090 Vienna, Austria

${ }^{6}$ Institute for Atmospheric and Environmental Sciences, Goethe University Frankfurt, 60438 Frankfurt am Main, Germany

${ }^{7}$ Universidade de Lisboa, Ed. C8, Campo Grande, 1749-016 Lisbon, Portugal

${ }^{8}$ CERN, Geneva, Switzerland

${ }^{9}$ Tofwerk AG, 3600 Thun, Switzerland

${ }^{10}$ School of Earth and Environmental Sciences, University of Manchester, Manchester, M13 9PL, UK

${ }^{11}$ IDL - Universidade da Beira Interior, Av. Marquês D’Avila e Bolama, 6201-001 Covilhã, Portugal

${ }^{12}$ Center for Atmospheric Particle Studies, Carnegie Mellon University, Pittsburgh, Pennsylvania, 15213, USA

${ }^{13}$ Division of Chemistry and Chemical Engineering, California Institute of Technology, Pasadena, California, 91125, USA

${ }^{14}$ University of Eastern Finland, Department of Applied Physics, 70211 Kuopio, Finland

${ }^{15}$ Aerodyne Research Inc., Billerica, Massachusetts, 01821, USA

${ }^{16}$ Department of Atmospheric and Oceanic Sciences, University of Colorado, Boulder, Colorado, 80309-0311, USA

${ }^{17}$ University of Tartu, Institute of Physics, 50090 Tartu, Estonia

${ }^{18}$ Ionicon Analytik GmbH, Eduard-Bodem Gasse 3, 6020 Innsbruck, Austria

${ }^{a}$ now at: Harvard University, School of Engineering and Applied Sciences, Cambridge, MA 02138, USA

b now at: Max-Planck Institute of Chemistry, Atmospheric Chemistry Department, 55128 Mainz, Germany

Correspondence: Josef Dommen (josef.dommen@psi.ch)

Received: 5 May 2017 - Discussion started: 29 May 2017

Revised: 31 October 2017 - Accepted: 10 November 2017 - Published: 4 January 2018

Published by Copernicus Publications on behalf of the European Geosciences Union. 
Abstract. It was recently shown by the CERN CLOUD experiment that biogenic highly oxygenated molecules (HOMs) form particles under atmospheric conditions in the absence of sulfuric acid, where ions enhance the nucleation rate by 1-2 orders of magnitude. The biogenic HOMs were produced from ozonolysis of $\alpha$-pinene at $5^{\circ} \mathrm{C}$. Here we extend this study to compare the molecular composition of positive and negative HOM clusters measured with atmospheric pressure interface time-of-flight mass spectrometers (APi-TOFs), at three different temperatures $\left(25,5\right.$ and $\left.-25^{\circ} \mathrm{C}\right)$. Most negative HOM clusters include a nitrate $\left(\mathrm{NO}_{3}^{-}\right)$ion, and the spectra are similar to those seen in the nighttime boreal forest. On the other hand, most positive HOM clusters include an ammonium $\left(\mathrm{NH}_{4}^{+}\right)$ion, and the spectra are characterized by mass bands that differ in their molecular weight by $\sim 20 \mathrm{C}$ atoms, corresponding to HOM dimers. At lower temperatures the average oxygen to carbon $(\mathrm{O}: \mathrm{C})$ ratio of the HOM clusters decreases for both polarities, reflecting an overall reduction of HOM formation with decreasing temperature. This indicates a decrease in the rate of autoxidation with temperature due to a rather high activation energy as has previously been determined by quantum chemical calculations. Furthermore, at the lowest temperature $\left(-25^{\circ} \mathrm{C}\right)$, the presence of $\mathrm{C}_{30}$ clusters shows that HOM monomers start to contribute to the nucleation of positive clusters. These experimental findings are supported by quantum chemical calculations of the binding energies of representative neutral and charged clusters.

\section{Introduction}

Atmospheric aerosol particles directly affect climate by influencing the transfer of radiant energy through the atmosphere (Boucher et al., 2013). In addition, aerosol particles can indirectly affect climate, by serving as cloud condensation nuclei (CCN) and ice nuclei (IN). They are of natural or anthropogenic origin, and result from direct emissions (primary particles) or from oxidation of gaseous precursors (secondary particles). Understanding particle formation processes in the atmosphere is important since more than half of the atmospheric aerosol particles may originate from nucleation (Dunne et al., 2016; Merikanto et al., 2009).

Due to its widespread presence and low saturation vapor pressure, sulfuric acid is believed to be the main vapor responsible for new particle formation (NPF) in the atmosphere. Indeed, particle nucleation is dependent on its concentration, albeit with large variability (Kulmala et al., 2004). The combination of sulfuric acid with ammonia and amines increases nucleation rates due to a higher stability of the initial clusters (Almeida et al., 2013; Kirkby et al., 2011; Kürten et al., 2016). However, these clusters alone cannot explain the particle formation rates observed in the atmosphere. Nucleation rates are greatly enhanced when oxidized organ- ics are present together with sulfuric acid, resulting in NPF rates that closely match those observed in the atmosphere (Metzger et al., 2010; Riccobono et al., 2014). An important characteristic of the organic molecules participating in nucleation is their high oxygen content and consequently low vapor pressure. The formation of these highly oxygenated molecules (HOMs) has been described by Ehn et al. (2014), who found that, following the well-known initial steps of $\alpha$ pinene ozonolysis through a Criegee intermediate leading to the formation of an $\mathrm{RO}_{2}$. radical, several repeated cycles of intramolecular hydrogen abstractions and $\mathrm{O}_{2}$ additions produce progressively more oxygenated $\mathrm{RO}_{2}$ radicals, a mechanism called autoxidation (Crounse et al., 2013). The (extremely) low volatility of the HOMs results in efficient NPF and growth, even in the absence of sulfuric acid (Kirkby et al., 2016; Tröstl et al., 2016). The chemical composition of HOMs during NPF has been identified from $\alpha$-pinene and pinanediol oxidation by Praplan et al. (2015) and Schobesberger et al. (2013), respectively.

Charge has also been shown to enhance nucleation (Kirkby et al., 2011). Ions are produced in the atmosphere mainly by galactic cosmic rays and radon. The primary ions are $\mathrm{N}^{+}, \mathrm{N}_{2}^{+}, \mathrm{O}^{+}, \mathrm{O}_{2}^{+}, \mathrm{H}_{3} \mathrm{O}^{+}, \mathrm{O}^{-}$and $\mathrm{O}_{2}^{-}$(Shuman et al., 2015). These generally form clusters with water (e.g., $\left.\left(\mathrm{H}_{2} \mathrm{O}\right) \mathrm{H}_{3} \mathrm{O}^{+}\right)$; after further collisions the positive and negative charges are transferred to trace species with highest and lowest proton affinities, respectively (Ehn et al., 2010). Ions are expected to promote NPF by increasing the cluster binding energy and reducing evaporation rates (Hirsikko et al., 2011). Recent laboratory experiments showed that ions increase the nucleation rates of HOMs from the oxidation of $\alpha$-pinene by $1-2$ orders of magnitude compared to neutral conditions (Kirkby et al., 2016). This is due to two effects, of which the first is more important: (1) an increase in cluster binding energy, which decreases evaporation, and (2) an enhanced collision probability, which increases the condensation of polar vapors on the charged clusters (Lehtipalo et al., 2016; Nadykto, 2003).

Temperature plays an important role in nucleation, resulting in strong variations of NPF at different altitudes. Kürten et al. (2016) studied the effect of temperature on nucleation for the sulfuric-acid-ammonia system, finding that low temperatures decrease the needed concentration of $\mathrm{H}_{2} \mathrm{SO}_{4}$ to maintain a certain nucleation rate. Similar results have been found for sulfuric-acid-water binary nucleation (Duplissy et al., 2016; Merikanto et al., 2016), where temperatures below $0{ }^{\circ} \mathrm{C}$ were needed for NPF to occur at atmospheric concentrations. Up to now, no studies have addressed the temperature effect on NPF driven by HOMs from biogenic precursors such as $\alpha$-pinene.

In this study we focus on the chemical characterization of the ions and the influence of temperature on their chemical composition during organic nucleation in the absence of sulfuric acid. The importance of such sulfuric-acid-free clusters for NPF has been shown in the laboratory (Kirkby et al., 
2016; Tröstl et al., 2016) as well as in the field (Bianchi et al., 2016). We present measurements of the NPF process from the detection of primary ions (e.g., $\mathrm{N}_{2}^{+}, \mathrm{O}_{2}^{+}, \mathrm{NO}^{+}$) to the formation of clusters in the size range of small particles, all under atmospherically relevant conditions. The experiments were conducted at three different temperatures $(-25,5$ and $25^{\circ} \mathrm{C}$ ) enabling the simulation of pure biogenic NPF representative of different tropospheric conditions. This spans the temperature range where NPF might occur in tropical or subtropical latitudes $\left(25^{\circ} \mathrm{C}\right)$, high-latitude boreal regions $\left(5^{\circ} \mathrm{C}\right)$ and the free troposphere $\left(-25^{\circ} \mathrm{C}\right)$. For example, NPF events were reported to occur in an Australian Eucalypt forest (Suni et al., 2008) and at the boreal station in Hyytiälä (Kulmala et al., 2013). Nucleation by organic vapors was also observed at a high mountain station (Bianchi et al, 2016). High aerosol particle concentrations were measured in the upper troposphere over the Amazon Basin and tentatively attributed to the oxidation of biogenic volatile organic compounds (Andreae et al., 2017).

\section{Methods}

\subsection{The CLOUD chamber}

We conducted experiments at the CERN CLOUD chamber (Cosmics Leaving Outdoor Droplets). With a volume of $26.1 \mathrm{~m}^{3}$, the chamber is built of electropolished stainless steel and equipped with a precisely controlled gas system. The temperature inside the chamber is measured with a string of six thermocouples (TC, type K), which were mounted horizontally between the chamber wall and the center of the chamber at distances of 100, 170, 270, 400, 650 and $950 \mathrm{~mm}$ from the chamber wall (Hoyle et al., 2016). The temperature is controlled accurately (with a precision of $\pm 0.1^{\circ} \mathrm{C}$ ) at any tropospheric temperature between -65 and $30^{\circ} \mathrm{C}$ (in addition, the temperature can be raised to $100^{\circ} \mathrm{C}$ for cleaning). The chamber enables atmospheric simulations under highly stable experimental conditions with low particle wall loss and low contamination levels (more details of the CLOUD chamber can be found in Kirkby et al., 2011 and Duplissy et al., 2016). At the beginning of the campaign the CLOUD chamber was cleaned by rinsing the walls with ultra-pure water, followed by heating to $100^{\circ} \mathrm{C}$ and flushing at a high rate with humidified synthetic air and elevated ozone (several ppmv) (Kirkby et al., 2016). This resulted in $\mathrm{SO}_{2}$ and $\mathrm{H}_{2} \mathrm{SO}_{4}$ concentrations that were below the detection limit ( $<15 \mathrm{pptv}$ and $<5 \times 10^{4} \mathrm{~cm}^{-3}$, respectively), and total organics (largely comprising high volatility $\mathrm{C}_{1}-\mathrm{C}_{3}$ compounds) that were below 150 pptv.

The air in the chamber is ionized by galactic cosmic rays (GCRs); higher ion generation rates can be induced by a pion beam $\left(\pi^{+}\right)$from the CERN Proton Synchrotron enabling controlled simulation of galactic cosmic rays throughout the troposphere. Therefore, the total ion-pair production rate in the chamber is between 2 (no beam) and $100 \mathrm{~cm}^{-3} \mathrm{~s}^{-1}$ (maximum available beam intensity, Franchin et al., 2015).

\subsection{Instrumentation}

The main instruments employed for this study were atmospheric pressure interface time-of-flight (APi-TOF, Aerodyne Research Inc. \& Tofwerk AG) mass spectrometers. The instrument has two main parts. The first is the atmospheric pressure interface $(\mathrm{APi})$, where ions are transferred from atmospheric pressure to low pressures via three differentially pumped vacuum stages. Ions are focused and guided by two quadrupoles and ion lenses. The second is the time-offlight mass analyzer (TOF), where the pressure is approximately $10^{-6}$ mbar. The sample flow from the chamber was $10 \mathrm{~L} \mathrm{~min}^{-1}$, and the core-sampled flow into the APi was $0.8 \mathrm{~L} \mathrm{~min}^{-1}$, with the remaining flow being discarded.

There is no direct chemical ionization in front of the instrument. The APi-TOF measures the positive or negative ions and cluster ions as they are present in the ambient atmosphere. As described above, in the CLOUD chamber ions are formed by GCRs or deliberately by the $\pi^{+}$beam, leading to ion concentrations of a few hundred to thousands per $\mathrm{cm}^{3}$, respectively. In our chamber the dominant ionizing species are $\mathrm{NH}_{4}^{+}$and $\mathrm{NO}_{3}^{-}$(see below). These ions mainly form clusters with the organic molecules, which is driven by the cluster energies. Therefore, the signals obtained do not provide a quantitative measure of the concentrations of the compounds. The higher the cluster energy with certain compounds, the higher the ion cluster concentration will be.

We calibrated the APi-TOF using trioctylammonium bis(trifluoromethylsulfonyl)imide (MTOA-B3FI, $\mathrm{C}_{27} \mathrm{H}_{54} \mathrm{~F}_{6} \mathrm{~N}_{2} \mathrm{O}_{4} \mathrm{~S}_{2}$ ) to facilitate exact ion mass determination in both positive and negative ion modes. We employed two calibration methods, the first one by nebulizing MTOA-B3FI and separating cluster ions with a high-resolution ultra-fine differential mobility analyzer (UDMA) (see Steiner et al., 2014 for more information); the second one by using electrospray ionization of a MTOA-B3FI solution. The calibration with the electrospray ionization was performed three times, one for each temperature. These calibrations enabled mass/charge $(\mathrm{m} / \mathrm{z})$ measurements with high accuracy up to $1500 \mathrm{Th}$ in the positive ion mode and $900 \mathrm{Th}$ in the negative ion mode.

Additionally, two peaks in the positive ion mode were identified as contaminants and also used for calibration purposes at the three different temperatures: $\mathrm{C}_{10} \mathrm{H}_{14} \mathrm{OH}^{+}$and $\mathrm{C}_{20} \mathrm{H}_{28} \mathrm{O}_{2} \mathrm{H}^{+}$. These peaks were present before the addition of ozone in the chamber (therefore being most likely not products of $\alpha$-pinene ozonolysis) and were also detected by a proton transfer reaction time-of-flight mass spectrometer (PTR-TOF-MS). Both peaks appeared at the same $m / z$ at all three temperatures. Therefore, based on the calibrations with the UDMA, the electrospray and the two organic cali- 
bration peaks, we expect an accurate mass calibration at the three temperatures.

\subsection{Experimental conditions}

All ambient ion composition data reported here were obtained during nucleation experiments from pure $\alpha$-pinene ozonolysis. The experiments were conducted under dark conditions, at a relative humidity $(\mathrm{RH})$ of $38 \%$ with an $\mathrm{O}_{3}$ mixing ratio between 33 and 43 ppbv (Table 1). The APiTOF measurements were made under both galactic cosmic ray (GCR) and $\pi^{+}$beam conditions, with ion-pair concentrations around 700 and $4000 \mathrm{~cm}^{-3}$, respectively.

\subsection{Quantum chemical calculations}

Quantum chemical calculations were performed on the cluster ion formation from the oxidation products of $\alpha$-pinene. The Gibbs free energies of formation of representative HOM clusters were calculated using the MO62X functional (Zhao and Truhlar, 2008), and the 6-31+G(d) basis set (Ditchfield, 1971) using the Gaussian09 program (Frisch et al., 2009). This method has been previously applied for clusters containing large organic molecules (Kirkby et al., 2016).

\section{Results and discussion}

\subsection{Ion composition}

Under dry conditions $(\mathrm{RH}=0 \%)$ and GCR ionization, the main detected positive ions were $\mathrm{N}_{2} \mathrm{H}^{+}$and $\mathrm{O}_{2}^{+}$. With increasing $\mathrm{RH}$ up to $\sim 30 \%$ we observed the water clusters $\mathrm{H}_{3} \mathrm{O}^{+},\left(\mathrm{H}_{2} \mathrm{O}\right) \cdot \mathrm{H}_{3} \mathrm{O}^{+}$and $\left(\mathrm{H}_{2} \mathrm{O}\right)_{2} \cdot \mathrm{H}_{3} \mathrm{O}^{+}$as well as $\mathrm{NH}_{4}^{+}$, $\mathrm{C}_{5} \mathrm{H}_{5} \mathrm{NH}^{+}$(protonated pyridine), $\mathrm{Na}^{+}$and $\mathrm{K}^{+}$(Fig. 1a). The concentrations of the precursors of some of the latter ions are expected to be very low; for example, $\mathrm{NH}_{3}$ mixing ratios were previously found to be in the range of $0.3 \mathrm{pptv}$ (at $-25^{\circ} \mathrm{C}$ ), 2 pptv (at $5^{\circ} \mathrm{C}$ ) and 4.3 pptv (at $25^{\circ} \mathrm{C}$ ) (Kürten et al., 2016). However, in a freshly cleaned chamber we expect ammonia levels below 1 pptv even at the higher temperatures. For the negative ions, $\mathrm{NO}_{3}^{-}$was the main detected background signal. Before adding any trace gas to the chamber the signal of $\mathrm{HSO}_{4}^{-}$was at a level of $1 \%$ of the $\mathrm{NO}_{3}^{-}$signal (corresponding to $<5 \times 10^{-4}$ molecules $\mathrm{cm}^{-3}$, Kirkby et al., 2016), excluding any contribution of sulfuric acid to nucleation in our experiments.

After initiating $\alpha$-pinene ozonolysis, more than 460 different peaks from organic ions were identified in the positive spectrum. The majority of peaks were clustered with $\mathrm{NH}_{4}^{+}$, while only $10.2 \%$ of the identified peaks were composed of protonated organic molecules. In both cases the organic core was of the type $\mathrm{C}_{7-10} \mathrm{H}_{10-16} \mathrm{O}_{1-10}$ for the monomer region and $\mathrm{C}_{17-20} \mathrm{H}_{24-32} \mathrm{O}_{5-19}$ for the dimer region.

In the negative spectrum we identified more than 530 HOMs, of which $\sim 62 \%$ corresponded to organic clusters with $\mathrm{NO}_{3}^{-}$or, to a lesser degree, $\mathrm{HNO}_{3} \cdot \mathrm{NO}_{3}^{-}$. The rest of the peaks were negatively charged organic molecules. In general, the organic core of the molecules was of the type $\mathrm{C}_{7-10} \mathrm{H}_{9-16} \mathrm{O}_{3-12}$ in the monomer region and $\mathrm{C}_{17-20} \mathrm{H}_{19-32} \mathrm{O}_{10-20}$ in the dimer region. For brevity we refer to the monomer, dimer (and $n$-mer) as $\mathrm{C}_{10}, \mathrm{C}_{20}$ (and $\mathrm{C}_{10 n}$ ), respectively. Here, the subscript indicates the maximum number of carbon atoms in these molecules, even though the bands include species with slightly fewer carbon atoms.

\subsubsection{Positive spectrum}

The positive spectrum is characterized by bands of high intensity at $\mathrm{C}_{20}$ intervals, as shown in Fig. 1b. Although we detected the monomer band $\left(\mathrm{C}_{10}\right)$, its integrated intensity was much lower than the $\mathrm{C}_{20}$ band; furthermore, the trimer and pentamer bands were almost completely absent. Based on chemical ionization mass spectrometry measurements, Kirkby et al. (2016) calculated that the HOM molar yield at $5{ }^{\circ} \mathrm{C}$ was $3.2 \%$ for the ozonolysis of $\alpha$-pinene, with a fractional yield of 10 to $20 \%$ for dimers. A combination reaction of two oxidized peroxy radicals has been previously reported to explain the rapid formation of dimers resulting in covalently bound molecules (see Sect. 3.3). The pronounced dimer signal with $\mathrm{NH}_{4}^{+}$indicates that (low-volatility) dimers are necessary for positive ion nucleation and initial growth. We observed growth by dimer steps up to $\mathrm{C}_{80}$ and possibly even $\mathrm{C}_{100}$. A cluster of two dimers, $\mathrm{C}_{40}$, with a mass/charge in the range of $\sim 700-1100 \mathrm{Th}$, has a mobility diameter around $1.5 \mathrm{~nm}$ (based on Ehn et al., 2011).

Our observation of $\mathrm{HOM}-\mathrm{NH}_{4}^{+}$clusters implies strong hydrogen bonding between the two species. This is confirmed by quantum chemical calculations which shall be discussed in Sect. 3.3. Although hydrogen bonding could also be expected between $\mathrm{HOMs}$ and $\mathrm{H}_{3} \mathrm{O}^{+}$, we do not observe such clusters. This probably arises from the higher proton affinity of $\mathrm{NH}_{3}, 203.6 \mathrm{kcal} \mathrm{mol}^{-1}$, compared with $\mathrm{H}_{2} \mathrm{O}$, $164.8 \mathrm{kcal} \mathrm{mol}^{-1}$ (Hunter and Lias, 1998). Thus, most $\mathrm{H}_{3} \mathrm{O}^{+}$ ions in CLOUD will transfer their proton to $\mathrm{NH}_{3}$ to form $\mathrm{NH}_{4}^{+}$.

\subsubsection{Negative spectrum}

In the negative spectra, the monomer, dimer, and trimer bands are observed during nucleation (Fig. 2). Monomers and dimers have similar signal intensities, whereas the trimer intensity is at least 10 times lower (Fig. 2a and b). The trimer signal is reduced since it is a cluster of two gas phase species $\left(\mathrm{C}_{10}+\mathrm{C}_{20}\right)$. Additionally, a lower transmission in the APiTOF may also be a reason for the reduced signal.

In Fig. 2, we compare the CLOUD negative-ion spectrum with the one from nocturnal atmospheric measurements from the boreal forest at Hyytiälä as reported by Ehn et al. (2010). Figure $2 a$ and $b$ show the negative spectrum of 
Table 1. Experiments performed at the CLOUD chamber.

\begin{tabular}{lclcclr}
\hline Campaign & $\begin{array}{c}\text { Experiment } \\
\text { no. }\end{array}$ & Ionization & $\begin{array}{c}\alpha \text {-pinene } \\
(\mathrm{pptv})\end{array}$ & $\begin{array}{c}\mathrm{O}_{3} \\
(\mathrm{ppbv})\end{array}$ & $\begin{array}{l}\text { Mass spectrometer } \\
\text { polarity }\end{array}$ & $\begin{array}{r}\text { Temperature } \\
\left({ }^{\circ} \mathrm{C}\right)\end{array}$ \\
\hline CLOUD 8 & 1211.02 & GCR & 258 & 33.8 & Negative & 5 \\
CLOUD 10 & 1710.04 & $\pi^{+}$beam & 618 & 41.5 & Positive & 5 \\
CLOUD 10 & 1712.04 & $\pi^{+}$beam & 511 & 40.3 & Negative and positive & 25 \\
CLOUD 10 & 1727.04 & $\pi^{+}$beam & 312 & 43.3 & Negative and positive & -25 \\
\hline
\end{tabular}

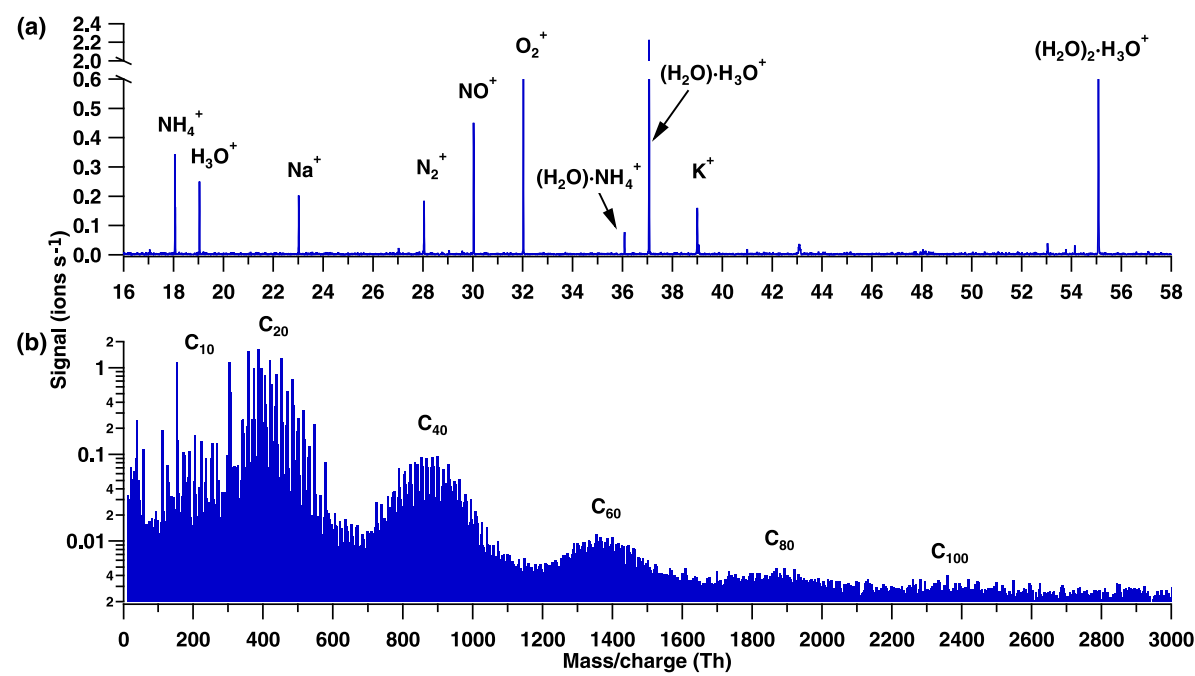

Figure 1. Positive spectra at $5^{\circ} \mathrm{C}$. (a) Low mass region, where primary ions from galactic cosmic rays are observed, as well as secondary ions such as $\mathrm{NH}_{4}^{+}$, which are formed by charge transfer to contaminants. (b) Higher mass region during pure biogenic nucleation, which shows broad bands in steps of $\mathrm{C}_{20}$. Most of the peaks represent clusters with $\mathrm{NH}_{4}^{+}$.

$\alpha$-pinene ozonolysis in the CLOUD chamber on logarithmic and linear scales, respectively. Figure 2c shows the Hyytiälä spectrum for comparison. Although the figure shows unit mass resolution, the high-resolution analysis confirms the identical composition for the main peaks: $\mathrm{C}_{8} \mathrm{H}_{12} \mathrm{O}_{7} \cdot \mathrm{NO}_{3}^{-}$, $\mathrm{C}_{10} \mathrm{H}_{14} \mathrm{O}_{7} \cdot \mathrm{NO}_{3}^{-}, \quad \mathrm{C}_{10} \mathrm{H}_{14} \mathrm{O}_{8} \cdot \mathrm{NO}_{3}^{-}, \quad \mathrm{C}_{10} \mathrm{H}_{14} \mathrm{O}_{9} \cdot \mathrm{NO}_{3}^{-}$, $\mathrm{C}_{10} \mathrm{H}_{16} \mathrm{O}_{10} \cdot \mathrm{NO}_{3}^{-}$and $\mathrm{C}_{10} \mathrm{H}_{14} \mathrm{O}_{11} \cdot \mathrm{NO}_{3}^{-}$(marked in the monomer region), and $\mathrm{C}_{19} \mathrm{H}_{28} \mathrm{O}_{11} \cdot \mathrm{NO}_{3}, \mathrm{C}_{19} \mathrm{H}_{28} \mathrm{O}_{12} \cdot \mathrm{NO}_{3}$, $\mathrm{C}_{20} \mathrm{H}_{30} \mathrm{O}_{12} \cdot \mathrm{NO}_{3}^{-}, \mathrm{C}_{19} \mathrm{H}_{28} \mathrm{O}_{14} \cdot \mathrm{NO}_{3}^{-}, \mathrm{C}_{20} \mathrm{H}_{30} \mathrm{O}_{14} \cdot \mathrm{NO}_{3}^{-}$, $\mathrm{C}_{20} \mathrm{H}_{32} \mathrm{O}_{15} \cdot \mathrm{NO}_{3}^{-}, \quad \mathrm{C}_{20} \mathrm{H}_{30} \mathrm{O}_{16} \cdot \mathrm{NO}_{3}^{-}, \quad \mathrm{C}_{20} \mathrm{H}_{30} \mathrm{O}_{17} \cdot \mathrm{NO}_{3}^{-}$ and $\mathrm{C}_{20} \mathrm{H}_{30} \mathrm{O}_{18} \cdot \mathrm{NO}_{3}^{-}$(marked in the dimer region). The close correspondence in terms of composition of the main HOMs from the lab and the field both in the monomer and dimer region indicates a close reproduction of the atmospheric nighttime conditions at Hyytiälä by the CLOUD experiment. In both cases the ion composition was dominated by HOMs clustered with $\mathrm{NO}_{3}^{-}$. However, Ehn et al. (2010) did not report nocturnal nucleation, possibly because of a higher ambient condensation sink than in the CLOUD chamber.

\subsection{Temperature dependence}

Experiments at three different temperatures $(25,5$ and $-25^{\circ} \mathrm{C}$ ) were conducted at similar relative humidity and ozone mixing ratios (Table 1 and Fig. 3). Mass defect plots are shown for the same data in Fig. 4. The mass defect is the difference between the exact and the integer mass and is shown on the $y$ axis versus the mass/charge on the $x$ axis. Each point represents a distinct atomic composition of a molecule or cluster. Although the observations described in the following are valid for both polarities, the trends at the three temperatures are better seen in the positive mass spectra due to a higher sensitivity at high $m / z$.

The first point to note is the change in the distribution of the signal intensity seen in Fig. 3 (height of the peaks) and in Fig. 4 (size of the dots) with temperature. In the positive ion mode, the dimer band has the highest intensity at 25 and $5^{\circ} \mathrm{C}$ (see also Fig. $1 \mathrm{~b}$ ), while at $-25^{\circ} \mathrm{C}$ the intensity of the monomer becomes comparable to that of the dimer. This indicates a reduced rate of dimer formation at $-25^{\circ} \mathrm{C}$, or that the intensity of the ion signal depends on both the concentration of the neutral compound and on the stability of the ion cluster. Although the monomer concentration is higher 
(a)

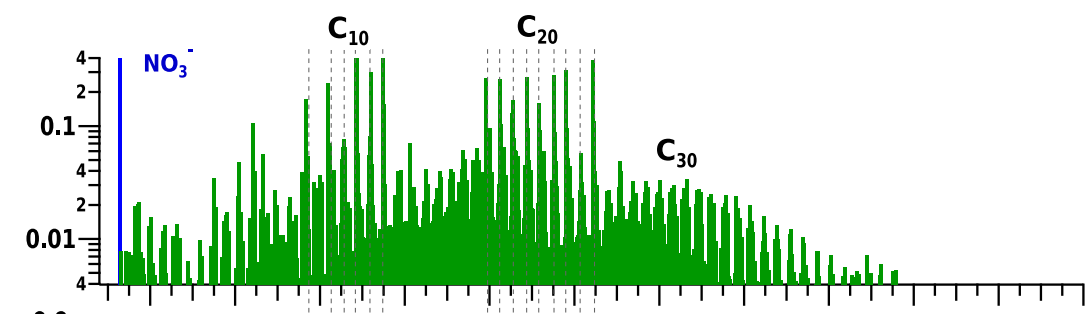

(b)

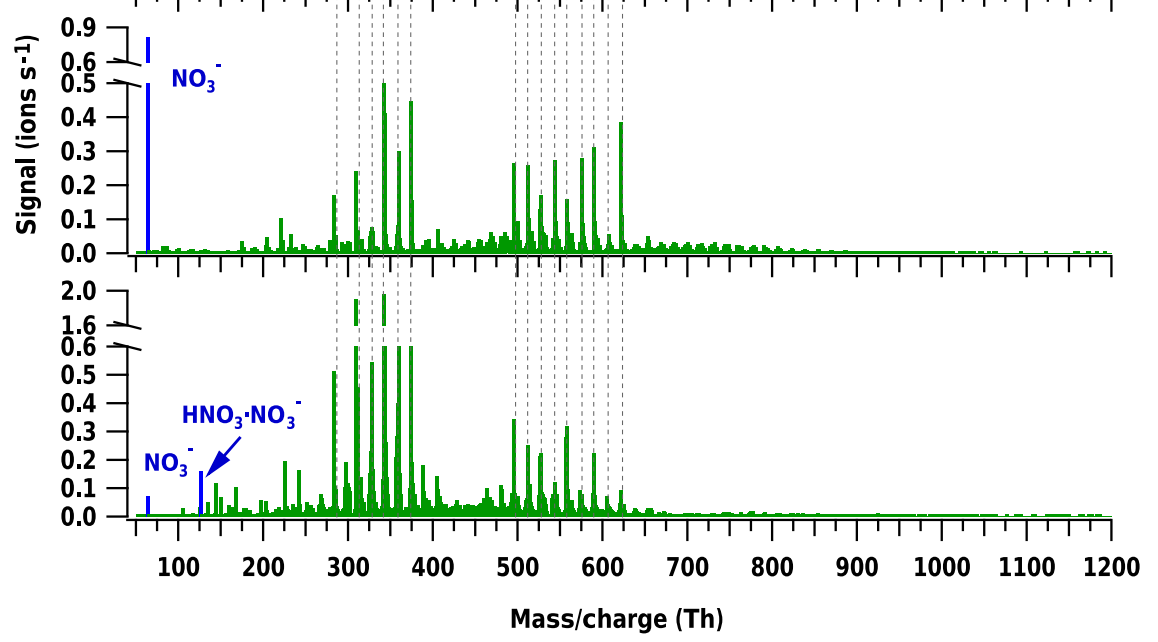

Figure 2. Comparison of the negative ion composition during $\alpha$-pinene ozonolysis in CLOUD and during nighttime in the boreal forest at Hyytiälä (Finland). (a) CLOUD spectrum on a logarithmic scale. (b) CLOUD spectrum on a linear scale. (c) Typical nighttime spectrum from the boreal forest at Hyytiälä (Finland), adapted from Ehn et al. (2010).

than that of the dimers (Tröstl et al., 2016), the $\mathrm{C}_{20}$ ions are the more stable ion clusters as they can form more easily two hydrogen bonds with $\mathrm{NH}_{4}^{+}$(see Sect. 3.3). Thus, positive clusters formed from monomers may not be stable enough at higher temperatures. Moreover, charge transfer to dimers is also favored.

The data also show a "shift" in all band distributions towards higher masses with increasing temperature, denoting a higher concentration of the more highly oxygenated molecules and the appearance of progressively more oxygenated compounds at higher temperatures. The shift is even more pronounced in the higher mass bands, as clearly seen in the $\mathrm{C}_{40}$ band of the positive ion mode in Fig. 3ac. In this case the combination of two HOM dimers to a $\mathrm{C}_{40}$ cluster essentially doubles the shift of the band towards higher mass/charge at higher temperatures compared to the $\mathrm{C}_{20}$ band. Moreover, the width of each band increases with temperature, as clearly seen in the positive ion mode in Fig. 4, especially for the $\mathrm{C}_{40}$ band. At high temperatures, the production of more highly oxygenated HOMs seems to increase the possible combinations of clusters, resulting in a wider band distribution.

This trend in the spectra indicates that the unimolecular autoxidation reaction accelerates at higher temperatures in competition to the bimolecular termination reactions with $\mathrm{HO}_{2}$ and $\mathrm{RO}_{2}$. This is expected. If unimolecular and bimolecular reactions are competitive, the unimolecu- lar process will have a much higher barrier because the preexponential term for a unimolecular process is a vibrational frequency while the pre-exponential term for the bimolecular process is at most the bimolecular collision frequency, which is 4 orders of magnitude lower. Quantum chemical calculations determine activation energies between 22.56 and $29.46 \mathrm{kcal} \mathrm{mol}^{-1}$ for the autoxidation of different $\mathrm{RO}_{2}$ radicals from $\alpha$-pinene (Rissanen et al., 2015). Thus, such a high barrier will strongly reduce the autoxidation rate at the low temperatures.

The change in the rate of autoxidation is also reflected in the $\mathrm{O}: \mathrm{C}$ ratio, both in the positive ion mode (Fig. 4ac), and the negative ion mode (Fig. 4d-f), showing a clear increase with increasing temperature. The average $\mathrm{O}: \mathrm{C}$ ratios (weighted by the peak intensities) are presented in Table 2 for both polarities and the three temperatures, for all the identified peaks (total) and separately for the monomer and dimer bands. For a temperature change from 25 to $-25^{\circ} \mathrm{C}$ the $\mathrm{O}: \mathrm{C}$ ratio decreases for monomers, dimers and total number of peaks. At high masses (e.g., for the $\mathrm{C}_{30}$ and $\mathrm{C}_{40}$ bands), the $\mathrm{O}: \mathrm{C}$ ratio may be slightly biased since accurate identification of the molecules is less straightforward: as an example, $\mathrm{C}_{39} \mathrm{H}_{56} \mathrm{O}_{25} \cdot \mathrm{NH}_{4}^{+}$has an exact mass-tocharge ratio of $942.34 \mathrm{Th}(\mathrm{O} / \mathrm{C}=0.64)$, which is very similar to $\mathrm{C}_{40} \mathrm{H}_{60} \mathrm{O}_{24} \cdot \mathrm{NH}_{4}^{+}$at $942.38 \mathrm{Th}(\mathrm{O} / \mathrm{C}=0.60)$. However, such possible misidentification would not influence the 


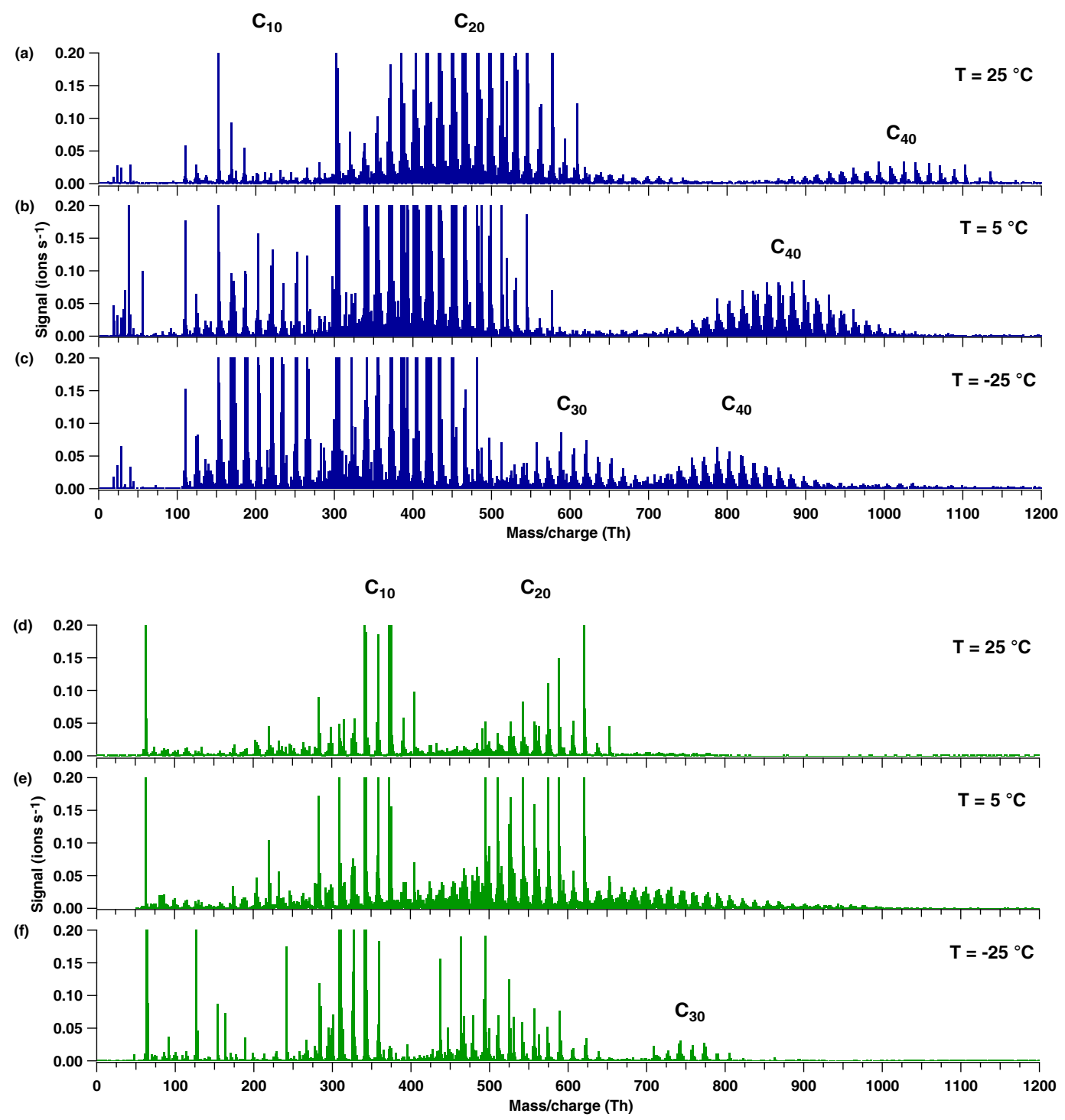

Figure 3. Positive (a-c) and negative (d-f) mass spectra during pure biogenic nucleation induced by ozonolysis of $\alpha$-pinene at three temperatures: $25^{\circ} \mathrm{C}(\mathbf{a}, \mathbf{d}), 5^{\circ} \mathrm{C}(\mathbf{b}, \mathbf{e})$ and $-25^{\circ} \mathrm{C}(\mathbf{c}, \mathbf{f})$. A progressive shift towards a lower oxygen content and lower masses is observed in all bands as the temperature decreases. Moreover, the appearance of $\mathrm{C}_{30}$ species can be seen in the positive spectrum at the lowest temperature (c).

Table 2. Signal weighted average $\mathrm{O}: \mathrm{C}$ ratios for positive and negative spectra at 25,5 and $-25^{\circ} \mathrm{C}$.

\begin{tabular}{|c|c|c|c|c|c|c|}
\hline \multirow{3}{*}{$\begin{array}{l}\text { Temperature } \\
\left({ }^{\circ} \mathrm{C}\right)\end{array}$} & \multicolumn{6}{|c|}{$\mathrm{O} / \mathrm{C}$} \\
\hline & \multicolumn{3}{|c|}{ Positive mode } & \multicolumn{3}{|c|}{ Negative mode } \\
\hline & Monomer & Dimer & Total & Monomer & Dimer & Total \\
\hline 25 & 0.37 & 0.57 & 0.54 & 0.94 & 0.81 & 0.90 \\
\hline 5 & 0.34 & 0.51 & 0.49 & 0.88 & 0.66 & 0.75 \\
\hline-25 & 0.31 & 0.38 & 0.36 & 0.79 & 0.65 & 0.68 \\
\hline
\end{tabular}

calculated total $\mathrm{O} / \mathrm{C}$ by more than 0.05 , and the main conclusions presented here remain robust.
The $\mathrm{O}: \mathrm{C}$ ratios are higher for the negative ions than for the positive ions at any of the three temperatures. Although some of the organic cores are the same in the positive and 

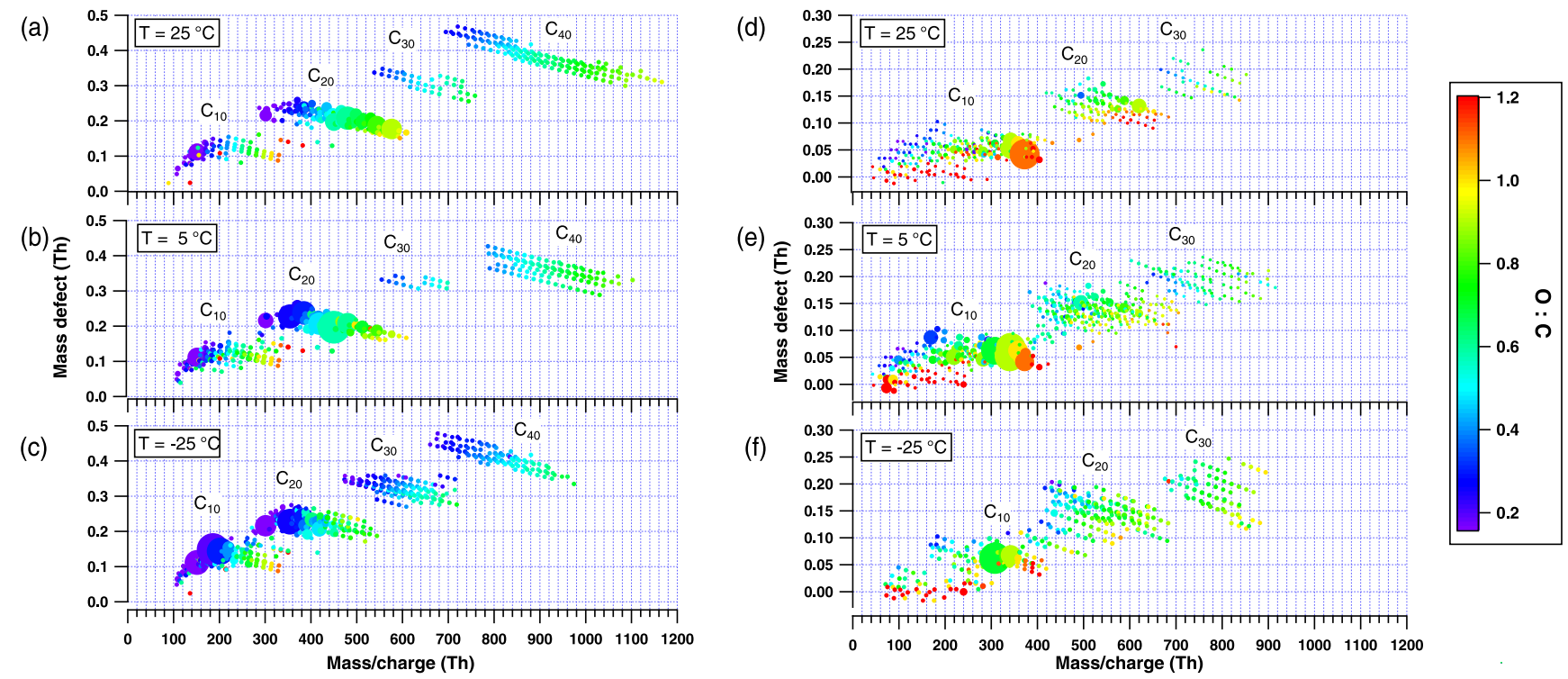

Figure 4. Mass defect plots with the color code denoting the $\mathrm{O}: \mathrm{C}$ ratio (of the organic core) at 25,5 and $-25^{\circ} \mathrm{C}$ for positive $(\mathbf{a}-\mathbf{c})$ and negative ion mode (d-f). A lower $\mathrm{O}: \mathrm{C}$ ratio is observed in the positive ion mode than in the negative ion mode. The intensity of the main peaks (linearly proportional to the size of the dots) changes with temperature for both polarities due to a lower degree of oxygenation at lower temperature.

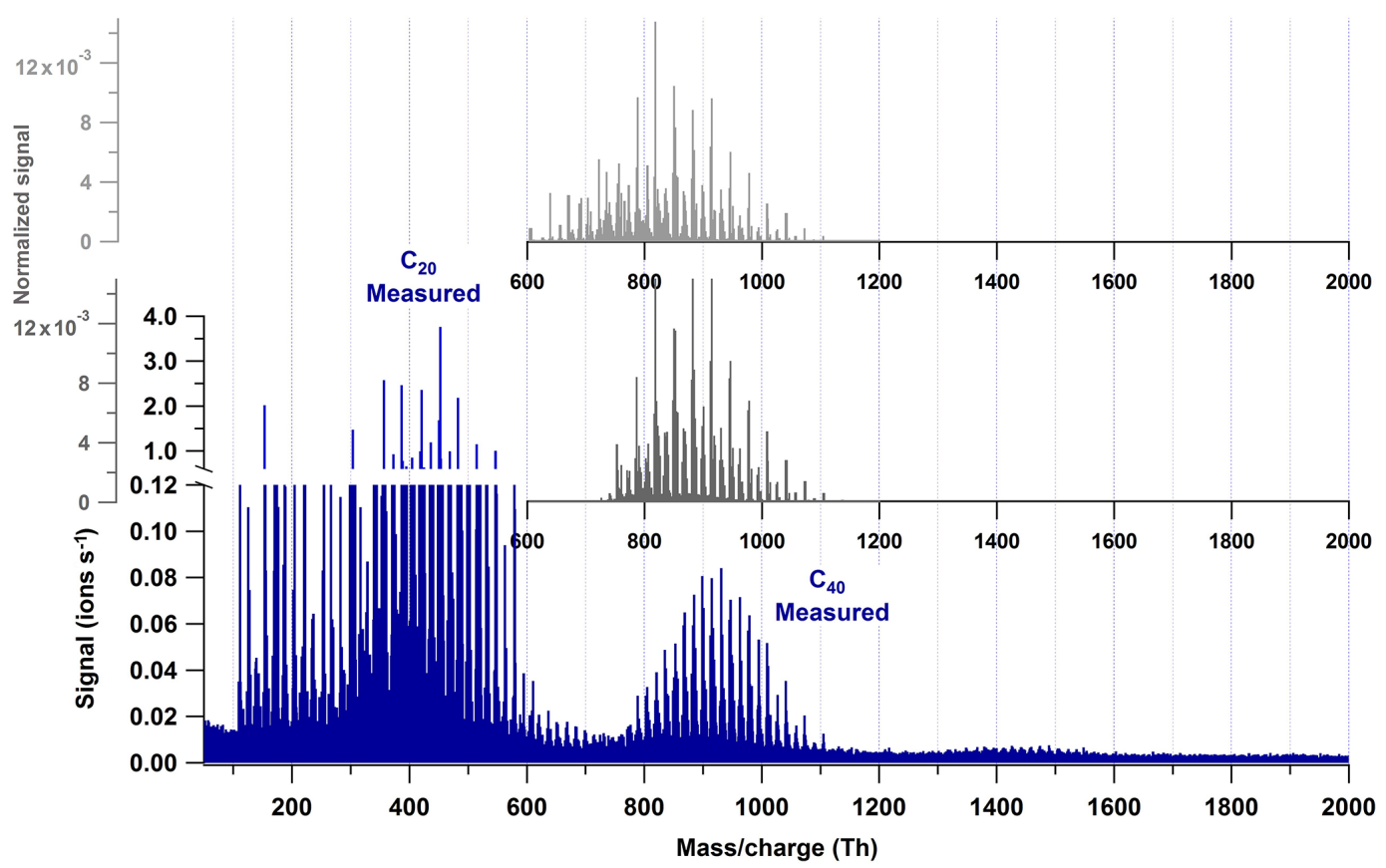

Figure 5. Comparison of the positive ion mode spectrum measured (blue), the $\mathrm{C}_{40}$ band obtained by the combination of all $\mathrm{C}_{20}$ molecules (light gray), and the $\mathrm{C}_{40}$ band obtained by combination of only the $\mathrm{C}_{20}$ molecules with $\mathrm{O} / \mathrm{C} \geq 0.4$ (dark gray). The low or absent signals at the lower masses obtained by permutation suggest that only the highly oxygenated dimers are able to cluster and form $\mathrm{C}_{40}$.

negative ion mode, the intensity of the peaks of the most oxygenated species is higher in the negative spectra. While the measured $\mathrm{O}: \mathrm{C}$ ratio ranges between 0.4 and 1.2 in the negative ion mode, it is between 0.1 and 1.2 in the pos- itive ion mode. An $\mathrm{O}: \mathrm{C}$ ratio of 0.1 , which was detected only in the positive ion mode, corresponds to monomers and dimers with two oxygen atoms. The presence of molecules with such low oxygen content was also confirmed with a pro- 
ton transfer reaction time-of-flight mass spectrometer (PTRTOF-MS), at least in the monomer region. Ions with $\mathrm{O}: \mathrm{C}$ ratio less than 0.3 are probably from the main known oxidation products like pinonaldehyde, pinonic acid, etc., but also from minor products like pinene oxide and other not yet identified compounds. It is likely that these molecules, which were detected only in the positive mode, contribute only to the growth of the newly formed particles (if at all) rather than to nucleation, owing to their high volatility (Tröstl et al., 2016). In this sense, the positive spectrum could reveal both the molecules that participate in the new particle formation and those that contribute to growth. The differences in the $\mathrm{O}: \mathrm{C}$ ratios between the two polarities are a result of the affinities of the organic molecules to form clusters either with $\mathrm{NO}_{3}^{-}$or $\mathrm{NH}_{4}^{+}$, which, in turn, depends on the molecular structure and the functional groups. Hyttinen et al. (2015) reported the binding energies of selected highly oxygenated products of cyclohexene detected by a nitrate CIMS, finding that the addition of $\mathrm{OOH}$ groups to the HOM strengthens the binding of the organic core with $\mathrm{NO}_{3}^{-}$. Even when the number of $\mathrm{H}$-bonds between $\mathrm{NO}_{3}^{-}$and HOM remains the same, the addition of more oxygen atoms to the organic compound could strengthen the binding with the $\mathrm{NO}_{3}^{-}$ion. Thus, the less oxygenated HOMs were not detected in those experiments, neither in ours, in the negative mode. The binding energies were calculated for the positive mode $\mathrm{HOMs}-\mathrm{NH}_{4}^{+}$and are discussed in Sect. 3.3.

We also tested to which extent the formation of the $\mathrm{C}_{40}$ band could be reproduced by permutation of the potential $\mathrm{C}_{20}$ molecules weighted by the dimer signal intensity. Figure 5 shows the measured spectrum (blue) and two types of modeled tetramers: one combining all peaks from the $\mathrm{C}_{20}$ band (light gray) and one combining only those peaks with an organic core with $\mathrm{O} / \mathrm{C} \geq 0.4$ - i.e., likely representing non-volatile $\mathrm{C}_{20}$ molecules (dark gray). The better agreement of the latter modeled mass spectrum of the tetramer band with the measured one suggests that only the molecules with $\mathrm{O} / \mathrm{C} \geq 0.4$ are able to form the tetramer cluster. This would mean that $\mathrm{C}_{20}$ molecules with 2-7 oxygen atoms are likely not to contribute to the nucleation, but only to the growth of the newly formed particles. One has to note that the comparison of modeled and measured spectra relies on the assumption that the charge distribution of dimers is also reflected in the tetramers.

These two observations (change in signal distribution and band "shift") are not only valid for positive and negative ions, but also for the neutral molecules as observed by two nitrate chemical-ionization atmospheric-pressure-interface time-offlight mass spectrometers (CI-APi-TOF; Aerodyne Research Inc. and Tofwerk AG). This confirms that there is indeed a change in the HOM composition with different temperature rather than a charge redistribution effect, which would only be observed for the ions (APi-TOF). The detailed analysis of the neutral molecules detected by these CI-APi-TOFs will be the subject of another paper and is not discussed here.

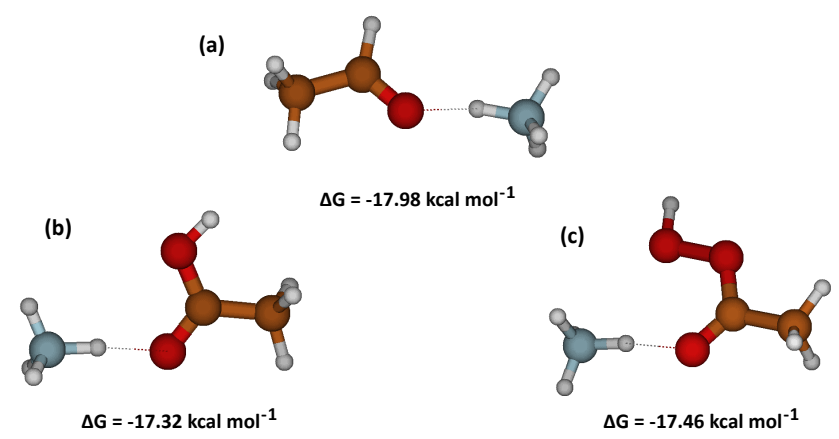

Figure 6. Quantum chemical calculations of the free energy related to the cluster formation between $\mathrm{NH}_{4}^{+}$and three structurally similar molecules with different functional groups: (a) acetaldehyde, (b) acetic acid and (c) peracetic acid.

A third distinctive trend in the positive mode spectra at the three temperatures is the increase in signal intensity of the $\mathrm{C}_{30}$ band at $-25^{\circ} \mathrm{C}$. The increase in the signal of the trimer also seems to occur in the negative ion mode when comparing Fig. 3d and f. For this polarity, data from two campaigns were combined (Table 1). To avoid a bias by possible differences in the APi-TOF settings, we only compare the temperatures from the same campaign, CLOUD 10, therefore experiments at 25 and $-25^{\circ} \mathrm{C}$. The increase in the trimer signal may be due to greater stability of the monomer-dimer clusters or even of three $\mathrm{C}_{10}$ molecules at low temperatures, as further discussed below.

\subsection{Quantum chemical calculations}

Three points were addressed in the quantum chemical calculations to elucidate the most likely formation pathway for the first clusters, and its temperature dependence. These included (i) the stability of the organic cores with $\mathrm{NO}_{3}^{-}$and $\mathrm{NH}_{4}^{+}$depending on the binding functional group, (ii) the difference between charged and neutral clusters in terms of clustering energies, and finally (iii) the possible nature of clusters in the dimer and trimer region.

The calculations showed that among the different functional groups the best interacting groups with $\mathrm{NO}_{3}^{-}$are in order of importance carboxylic acids $(\mathrm{R}-\mathrm{C}(=\mathrm{O})-\mathrm{OH})$, hydroxyls $(\mathrm{R}-\mathrm{OH})$, peroxy acids $(\mathrm{R}-\mathrm{C}(=\mathrm{O})-\mathrm{O}-\mathrm{OH})$, hydroperoxides $(\mathrm{R}-\mathrm{O}-\mathrm{OH})$ and carbonyls $\left(\mathrm{R}-\left(\mathrm{R}^{\prime}-\right) \mathrm{C}=\mathrm{O}\right)$. On the other hand, $\mathrm{NH}_{4}^{+}$preferably forms a hydrogen bond with the carbonyl group independent of which functional group the carbonyl group is linked to; Fig. 6 shows examples of $\mathrm{NH}_{4}^{+}$clusters with corresponding free energies of formation for carbonyls $\left(\Delta G=-17.98 \mathrm{kcal} \mathrm{mol}^{-1}\right)$, carboxylic acid $\left(\Delta G=-17.32 \mathrm{kcal} \mathrm{mol}^{-1}\right)$ and peroxy acid $\left(\Delta G=-17.46 \mathrm{kcal} \mathrm{mol}^{-1}\right)$. For the three examples shown, the interaction of one hydrogen from $\mathrm{NH}_{4}^{+}$with a $\mathrm{C}=\mathrm{O}$ group is already very stable with a free energy of cluster ion formation close to $-18 \mathrm{kcal} \mathrm{mol}^{-1}$. 


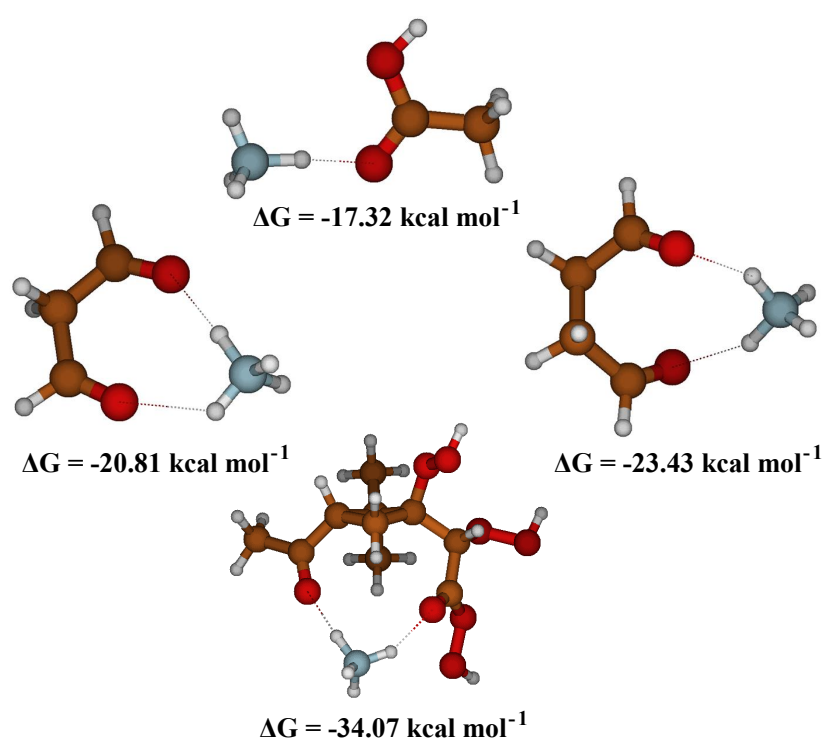

Figure 7. Quantum chemical calculations for different organic molecules with a carbonyl as the interacting functional group with $\mathrm{NH}_{4}^{+}$. Increasing the interacting groups from one to two increases the stability of the cluster. The distance between the interacting groups also influences the cluster stability.

To evaluate the effect of the presence of a second $\mathrm{C}=\mathrm{O}$ on the binding of the organic compound with $\mathrm{NH}_{4}^{+}$, we performed a series of calculations with a set of surrogates containing two $\mathrm{C}=\mathrm{O}$ groups separated by different numbers of atoms, as shown in Fig. 7. The addition of a second functional group allows the formation of an additional hydrogen bond, increasing the stability of the cluster considerably (almost 2 -fold) from about -18 to $-34.07 \mathrm{kcal} \mathrm{mol}^{-1}$, whereby the position of the second functional group to form an optimal hydrogen bond (with a $180^{\circ}$ angle for $\mathrm{N}-\mathrm{H}-\mathrm{O}$ ) strongly influences the stability of the cluster, as can be seen in Fig. 7. Thus, optimal separation and conformational flexibility of functional groups is needed to enable effective formation of two hydrogen bonds with $\mathrm{NH}_{4}^{+}$. This could be an explanation for the observation that the signal intensity is higher for dimers than for monomers, as dimers can more easily form two optimal hydrogen bonds with $\mathrm{NH}_{4}^{+}$.

As shown by Kirkby et al. (2016), ions increase the nucleation rates by $1-2$ orders of magnitudes compared to neutral nucleation. This is expected due to the strong electrostatic interaction between charged clusters. To understand how the stability difference relates to the increase in the nucleation rate, the $\Delta G$ of charged and neutral clusters were compared. For this, $\mathrm{C}_{10} \mathrm{H}_{14} \mathrm{O}_{7}$ and $\mathrm{C}_{20} \mathrm{H}_{30} \mathrm{O}_{14}$ were selected as representative molecules of the monomer and dimer region, respectively (Kirkby et al., 2016). Table 3 shows the calculated free energies of formation $(\Delta G)$ of neutral, positive and negative clusters from these $C_{10}$ and $C_{20}$ molecules at the three temperatures of the experiment. Results show that

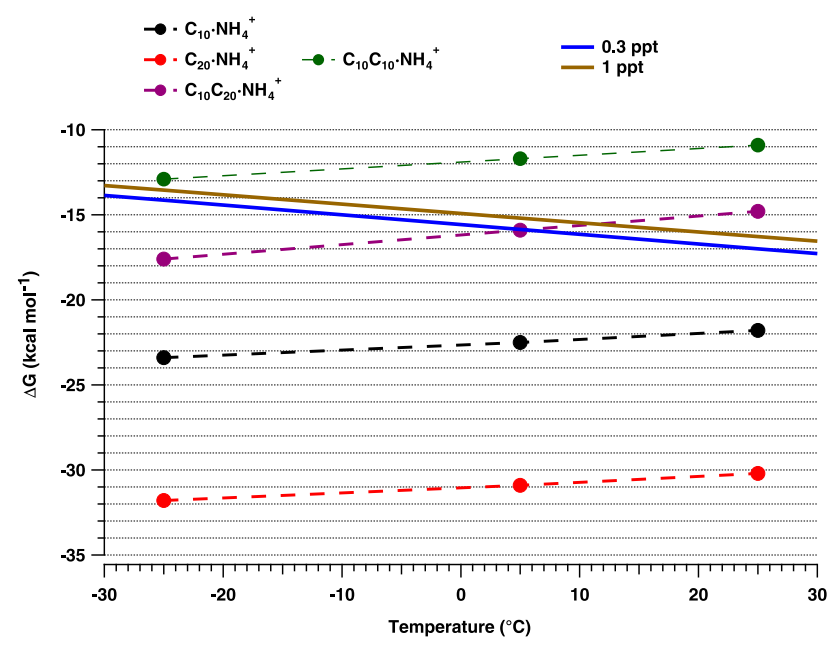

Figure 8. Quantum chemical calculations of Gibbs free energies for cluster formation at $-25,5$ and $25^{\circ} \mathrm{C}$. Solid lines represent the required $\Delta G$ for equilibrium between evaporation and collision rates at 0.3 and 1 pptv of the HOM mixing ratio, respectively. Markers show the $\Delta G$ for each cluster (organic core clustered with $\mathrm{NH}_{4}^{+}$) at the three temperatures. $\mathrm{C}_{10} \cdot \mathrm{NH}_{4}^{+}$(black circles) represent the monomer, $\mathrm{C}_{20} \cdot \mathrm{NH}_{4}^{+}$(red circles) represent the covalently bound dimer, $\mathrm{C}_{10} \mathrm{C}_{10} \cdot \mathrm{NH}_{4}^{+}$(green circles) represent the dimer formed by the clustering of two monomers and $\mathrm{C}_{10} \mathrm{C}_{20} \cdot \mathrm{NH}_{4}^{+}$(purple circles) denote the preferential pathway for the trimer cluster (see Table 3 ).

at $5{ }^{\circ} \mathrm{C}$, for example, $\Delta G$ of the neutral dimer $\left(\mathrm{C}_{10}+\mathrm{C}_{10}\right)$ is $-5.76 \mathrm{kcal} \mathrm{mol}^{-1}$ while it decreases to $-20.9 \mathrm{kcal} \mathrm{mol}^{-1}$ when a neutral and a negative ion form a cluster $\left(\mathrm{C}_{10}+\mathrm{C}_{10}^{-}\right)$. Similarly, trimers show a substantial increase in stability when they are charged - i.e., from -2.1 to $-19.9 \mathrm{kcal} \mathrm{mol}^{-1}$, for the neutral and negative cases, respectively. The reduced values of $\Delta G$ for the charged clusters (positive and negative) indicate a substantial decrease in the evaporation rate compared to that for neutral clusters, and, therefore, higher stability. Comparing the $\mathrm{NH}_{4}^{+}$and $\mathrm{NO}_{3}^{-}$clusters, the energies of formation for the monomer are -22.5 and $-25.9 \mathrm{kcal} \mathrm{mol}^{-1}$, respectively, showing slightly higher stability for the negative cluster. Inversely, the covalently bound dimer showed greater stability for the positive ion $\left(-30.9 \mathrm{kcal} \mathrm{mol}^{-1}\right)$ compared to the negative ion $\left(-25.6 \mathrm{kcal} \mathrm{mol}^{-1}\right)$.

The temperature dependence of cluster formation is shown in Fig. 8 for the positive ion clusters. The blue and brown solid lines represent the needed $\Delta G$ for evaporationcollision equilibrium at 0.3 and $1 \mathrm{pptv}$ HOM mixing ratio, respectively, calculated as described by Ortega et al. (2012). The markers show the calculated formation enthalpies $\Delta G$ for each of the possible clusters. For all cases, the trend shows an evident decrease in $\Delta G$ with decreasing temperature, with a correspondingly reduced evaporation rate. 
Table 3. Gibbs free energies of cluster formation $\Delta G$ at three different temperatures. $\Delta G$ for the molecules $\mathrm{C}_{10} \mathrm{H}_{14} \mathrm{O}_{7}\left(\mathrm{C}_{10}\right)$ and $\mathrm{C}_{20} \mathrm{H}_{30} \mathrm{O}_{14}$ $\left(\mathrm{C}_{20}\right)$ forming neutral, as well as negative and positive ion clusters.

\begin{tabular}{llrrr}
\hline & Cluster process & $\begin{array}{r}\Delta G_{-25^{\circ} \mathrm{C}} \\
\left(\mathrm{kcal} \mathrm{mol}^{-1}\right)\end{array}$ & $\begin{array}{r}\Delta G_{5}{ }^{\circ} \mathrm{C} \\
\left(\mathrm{kcal} \mathrm{mol}^{-1}\right)\end{array}$ & $\begin{array}{r}\Delta G_{25}{ }^{\circ} \mathrm{C} \\
\left(\mathrm{kcal} \mathrm{mol}^{-1}\right)\end{array}$ \\
\hline \multirow{2}{*}{ Neutral } & $\mathrm{C}_{10}+\mathrm{C}_{10}$ & -7.3 & -5.7 & -4.7 \\
& $\mathrm{C}_{10}+\mathrm{C}_{20}$ & -3.2 & -2.1 & -1.4 \\
\hline \multirow{2}{*}{ Positive } & $\mathrm{C}_{10}+\mathrm{NH}_{4}^{+}$ & -23.4 & -22.5 & -21.8 \\
& $\mathrm{C}_{20}+\mathrm{NH}_{4}^{+}$ & -31.8 & -30.9 & -30.2 \\
& $\mathrm{C}_{10}+\mathrm{C}_{10} \cdot \mathrm{NH}_{4}^{+}$ & -12.9 & -11.7 & -10.9 \\
& $\mathrm{C}_{20}+\mathrm{C}_{10} \cdot \mathrm{NH}_{4}^{+}$ & -26.0 & -24.3 & -23.3 \\
& $\mathrm{C}_{10}+\mathrm{C}_{20} \cdot \mathrm{NH}_{4}^{+}$ & -17.6 & -15.9 & -14.8 \\
\hline \multirow{2}{*}{ Negative } & $\mathrm{C}_{10}+\mathrm{C}_{10}^{-}$ & -22.2 & -20.9 & -20.1 \\
& $\mathrm{C}_{20}+\mathrm{C}_{10}^{-}$ & -21.3 & -19.9 & -18.9 \\
& $\mathrm{C}_{10}+\mathrm{NO}_{3}^{-}$ & -27.3 & -25.9 & -25.1 \\
& $\mathrm{C}_{20}+\mathrm{NO}_{3}^{-}$ & -26.9 & -25.6 & -24.7 \\
& $\mathrm{C}_{10}+\mathrm{C}_{10} \cdot \mathrm{NO}_{3}^{-}$ & -11.3 & -10.1 & -9.2 \\
\hline
\end{tabular}

At all three temperatures, the monomer cluster $\mathrm{C}_{10} \cdot \mathrm{NH}_{4}^{+}$ falls well below the equilibrium lines, indicating high stability. Even though the difference between -25 and $25^{\circ} \mathrm{C}$ is just $-1.6 \mathrm{kcal} \mathrm{mol}^{-1}$ in free energy, it is enough to produce a substantial difference in the intensity of the band, increasing the signal at least 8 -fold at $-25^{\circ} \mathrm{C}$ (as discussed in Sect. 3.2). In the case of the dimers, we consider the possibility of their formation by collision of a monomer $\mathrm{C}_{10} \cdot \mathrm{NH}_{4}^{+}$ with another $\mathrm{C}_{10}$ (resulting in a $\mathrm{C}_{10} \mathrm{C}_{10} \cdot \mathrm{NH}_{4}^{+}$cluster) or the dimer as $\mathrm{C}_{20} \cdot \mathrm{NH}_{4}^{+}$cluster. The calculations show clearly that the cluster $\mathrm{C}_{10} \mathrm{C}_{10} \cdot \mathrm{NH}_{4}^{+}$is not stable at any of the three temperatures (green line). In contrast, the covalently bound $\mathrm{C}_{20}$ forms very stable positive and negative ion clusters (see Table 3). Trimers are mainly observed at lower temperatures. Since the $\mathrm{C}_{10} \mathrm{C}_{10} \cdot \mathrm{NH}_{4}^{+}$cluster is not very stable, we discard the possibility of a trimer formation of the type $\mathrm{C}_{10} \mathrm{C}_{10} \mathrm{C}_{10} \cdot \mathrm{NH}_{4}^{+}$. Thus, the trimer is likely the combination of a monomer and a covalently bound $\operatorname{dimer}\left(\mathrm{C}_{20} \mathrm{C}_{10} \cdot \mathrm{NH}_{4}^{+}\right)$. According to our calculations (Table 3 ) the preferred evaporation path for this cluster is the loss of $\mathrm{C}_{10}$ rather than the evaporation of $\mathrm{C}_{20}$. Therefore, we have chosen to represent only this path in Fig. 8. The $\Delta G$ of this cluster crosses the evaporation-condensation equilibrium around 5 and $14{ }^{\circ} \mathrm{C}$ for a HOM mixing ratio of 0.3 and 1 pptv, respectively, in good agreement with the observed signal increase of the trimer at $-25^{\circ} \mathrm{C}$ (Fig. 3a-c). It is important to note that, due to the uncertainty in the calculations, estimated to be $\leq 2 \mathrm{kcal} \mathrm{mol}^{-1}$, we do not consider the crossing as an exact reference.

The $\Delta G$ of the negative ion clusters, which are also presented in Table 3, decrease similarly to the positive ion clusters by around $2 \mathrm{kcal} \mathrm{mol}^{-1}$ between 25 and $-25^{\circ} \mathrm{C}$. The cluster formation energies of the monomer and the dimer with $\mathrm{NO}_{3}^{-}$are in agreement with the observed comparable signal intensity in the spectrum (Fig. 2) in a similar way as the positive ion clusters. The covalently bonded dimer ion $\mathrm{C}_{20} \cdot \mathrm{NO}_{3}^{-}$is also more stable compared to the dimer cluster $\mathrm{C}_{10} \mathrm{C}_{10} \cdot \mathrm{NO}_{3}^{-}$, suggesting that the observed composition results from covalently bonded dimers clustering with $\mathrm{NO}_{3}^{-}$ rather than two individual $\mathrm{C}_{10}$ clustering to form a dimer.

The formation of a covalently bonded trimer seems unlikely, so the formation of highly oxygenated molecules is restricted to the monomer and dimer region. The trimer could result from the clustering of $\mathrm{C}_{10}$ and $\mathrm{C}_{20}$ species. Similarly, and based on the $\mathrm{C}_{20}$ pattern observed in Fig. $1 \mathrm{~b}$, we believe that the formation of the tetramer corresponds to the collision of two dimers. No calculations were done for this case due to the complexity related to the sizes of the molecules, which prevents feasible high-level quantum chemical calculations.

Finally, a comparison of the $\Delta G$ values as presented in Table 3 confirms the expected higher stability of charged clusters compared to neutral clusters, decreasing the evaporation rate of the nucleating clusters and enhancing new particle formation.

\section{Conclusions}

Ions observed during pure biogenic ion-induced nucleation were comprised of mainly organics clustered with $\mathrm{NO}_{3}^{-}$and $\mathrm{NH}_{4}^{+}$and to a lesser extent charged organic molecules only or organics clustered with $\mathrm{HNO}_{3} \mathrm{NO}_{3}^{-}$. We found good correspondence between the negative ions measured in CLOUD and those observed in the boreal forest of Hyytiälä. The observed similarity in the composition of the HOMs in the monomer and dimer region during new-particle formation experiments at CLOUD suggests that pure biogenic nucleation might be possible during nighttime if the condensation sink is sufficiently low - i.e., comparable to that in the 
CLOUD chamber, where the wall loss rate for $\mathrm{H}_{2} \mathrm{SO}_{4}$ is $1.8 \times 10^{-3} \mathrm{~s}^{-1}$ (Kirkby et al., 2016). The positive mass spectrum showed a distinctive pattern corresponding to progressive addition of dimers $\left(\mathrm{C}_{20}\right)$, up to cluster sizes in the range of stable small particles.

Temperature strongly influenced the composition of the detected molecules in several ways. With increasing temperature, a higher oxygen content $(\mathrm{O}: \mathrm{C}$ ratio) in the molecules was observed in both the positive and the negative mode. This indicates an increase in the autoxidation rate of peroxy radicals, which is in competition with their bimolecular termination reactions with $\mathrm{HO}_{2}$ and $\mathrm{RO}_{2}$.

A broader range of organic molecules was found to form clusters with $\mathrm{NH}_{4}^{+}$than with $\mathrm{NO}_{3}^{-}$. Quantum chemical calculations using simplified molecules show that $\mathrm{NH}_{4}^{+}$preferably forms a hydrogen bond with a carbonyl group independently of other functional groups nearby. The addition of a second hydrogen bond was found to increase the cluster stability substantially. Thus, the $\mathrm{C}_{20}$ ions are the more stable ion clusters as they can form more easily two hydrogen bonds with $\mathrm{NH}_{4}^{+}$. Although molecules with low oxygen content were measured in the $\mathrm{C}_{20}$ band (1-4 oxygen atoms), only the molecules with $\mathrm{O} / \mathrm{C} \geq 0.4$ seem to be able to combine to form larger clusters.

The quantum chemical calculations showed that the covalently bonded dimer $\mathrm{C}_{20} \cdot \mathrm{NO}_{3}^{-}$is also more stable than the dimer cluster $\mathrm{C}_{10} \mathrm{C}_{10} \cdot \mathrm{NO}_{3}^{-}$, suggesting that the observed composition results from covalently bonded molecules clustering with $\mathrm{NO}_{3}^{-}$rather than $\mathrm{C}_{10}$ clusters.

Temperature affected cluster formation by decreasing evaporation rates at lower temperatures, despite the lower $\mathrm{O}: \mathrm{C}$ ratio. In the positive mode a pronounced growth of clusters by addition of $\mathrm{C}_{20}-\mathrm{HOMs}$ was observed. The formation of a $\mathrm{C}_{30}$ cluster only appeared at the lowest temperature, which was supported by quantum chemical calculations. In the negative mode it appeared as well that the signal of the $\mathrm{C}_{30}$ clusters became stronger with lower temperature. The $\mathrm{C}_{40}$ and higher clusters were probably not seen because of too low sensitivity in this mass range due to the applied instrumental settings. More measurements are needed to determine if the cluster growth of positive and negative ions proceeds in a similar or different way.

Nucleation and early growth is driven by the extremely low volatility compounds - i.e., dimers and monomers of high O : C ratios (Tröstl et al., 2016). Here, we observe a reduction of the autoxidation rate leading to oxidation products with lower $\mathrm{O}: \mathrm{C}$ ratios with decreasing temperature. We expect that this is accompanied by a reduction of nucleation rates. However, a lower temperature reduces evaporation rates of clusters and thereby supports nucleation. The relative magnitude of these compensating effects will be subject of further investigations.
Data availability. Data related to this article are available online at https://doi.org/10.5281/zenodo.1133985.

Competing interests. The authors declare that they have no conflict of interest.

Acknowledgements. We would like to thank CERN for supporting CLOUD with important technical and financial resources, and for providing a particle beam from the CERN Proton Synchrotron. We also thank P. Carrie, L.-P. De Menezes, J. Dumollard, K. Ivanova, F. Josa, I. Krasin, R. Kristic, A. Laassiri, O. S. Maksumov, B. Marichy, H. Martinati, S. V. Mizin, R. Sitals, A. Wasem and M. Wilhelmsson for their important contributions to the experiment. This research has received funding from the EC Seventh Framework Programme (Marie Curie Initial Training Network CLOUD-ITN no. 215072, MC-ITN CLOUD-TRAIN no. 316662, the ERC-Starting grant MOCAPAF no. 57360, the ERC-Consolidator grant NANODYNAMITE no. 616075 and ERC-Advanced grant ATMNUCLE no. 227463), European Union's Horizon 2020 research and innovation programme under the Marie Skłodowska-Curie grant agreement no. 656994, the PEGASOS project funded by the European Commission under the Framework Programme 7 (FP7-ENV-2010-265148), the German Federal Ministry of Education and Research (project nos. 01LK0902A and 01LK1222A), the Swiss National Science Foundation (project nos. 200020_152907, 206021_144947 and 20FI20_159851), the Academy of Finland (Center of Excellence project no. 1118615), the Academy of Finland (135054, 133872, 251427, 139656, 139995, 137749, 141217, 141451, 299574), the Finnish Funding Agency for Technology and Innovation, the Väisälä Foundation, the Nessling Foundation, the University of Innsbruck research grant for young scientists (Cluster Calibration Unit), the Portuguese Foundation for Science and Technology (project no. CERN/FP/116387/2010), the Swedish Research Council, Vetenskapsrådet (grant 2011-5120), the Presidium of the Russian Academy of Sciences and Russian Foundation for Basic Research (grants 08-02-91006-CERN and 12-02-91522-CERN), the US National Science Foundation (grants AGS1447056, and AGS1439551), and the Davidow Foundation. We thank the tofTools team for providing tools for mass spectrometry analysis.

Edited by: Sergey A. Nizkorodov

Reviewed by: two anonymous referees

\section{References}

Almeida, J., Schobesberger, S., Kürten, A., Ortega, I. K., Kupiainen-Määttä, O., Praplan, A. P., Adamov, A., Amorim, A., Bianchi, F., Breitenlechner, M., David, A., Dommen, J., Donahue, N. M., Downard, A., Dunne, E., Duplissy, J., Ehrhart, S., Flagan, R. C., Franchin, A., Guida, R., Hakala, J., Hansel, A., Heinritzi, M., Henschel, H., Jokinen, T., Junninen, H., Kajos, M., Kangasluoma, J., Keskinen, H., Kupc, A., Kurtén, T., Kvashin, A. N., Laaksonen, A., Lehtipalo, K., Leiminger, M., Leppä, J., Loukonen, V., Makhmutov, V., Mathot, S., McGrath, M. J., Nieminen, T., Olenius, T., Onnela, A., Petäjä, T., Riccobono, F., 
Riipinen, I., Rissanen, M., Rondo, L., Ruuskanen, T., Santos, F. D., Sarnela, N., Schallhart, S., Schnitzhofer, R., Seinfeld, J. H., Simon, M., Sipilä, M., Stozhkov, Y., Stratmann, F., Tomé, A., Tröstl, J., Tsagkogeorgas, G., Vaattovaara, P., Viisanen, Y., Virtanen, A., Vrtala, A., Wagner, P. E., Weingartner, E., Wex, H., Williamson, C., Wimmer, D., Ye, P., Yli-Juuti, T., Carslaw, K. S., Kulmala, M., Curtius, J., Baltensperger, U., Worsnop, D. R., Vehkamäki, H., and Kirkby, J.: Molecular understanding of sulphuric acid-amine particle nucleation in the atmosphere, Nature, 502, 359-363, https://doi.org/10.1038/nature12663, 2013.

Andreae, M. O., Afchine, A., Albrecht, R., Holanda, B. A., Artaxo, P., Barbosa, H. M. J., Bormann, S., Cecchini, M. A., Costa, A., Dollner, M., Fütterer, D., Järvinen, E., Jurkat, T., Klimach, T., Konemann, T., Knote, C., Krämer, M., Krisna, T., Machado, L. A. T., Mertes, S., Minikin, A., Pöhlker, C., Pöhlker, M. L., Pöschl, U., Rosenfeld, D., Sauer, D., Schlager, H., Schnaiter, M., Schneider, J., Schulz, C., Spanu, A., Sperling, V. B., Voigt, C., Walser, A., Wang, J., Weinzierl, B., Wendisch, M., and Ziereis, H.: Aerosol characteristics and particle production in the upper troposphere over the Amazon Basin, Atmos. Chem. Phys. Discuss., https://doi.org/10.5194/acp-2017-694, in review, 2017.

Bianchi, F., Tröstl, J., Junninen, H., Frege, C., Henne, S., Hoyle, C. R., Molteni, U., Herrmann, E., Adamov, A., Bukowiecki, N., Chen, X., Duplissy, J., Gysel, M., Hutterli, M., Kangasluoma, J., Kontkanen, J., Kürten, A., Manninen, H. E., Münch, S., Peräkylä, O., Petäjä, T., Rondo, L., Williamson, C., Weingartner, E., Curtius, J., Worsnop, D. R., Kulmala, M., Dommen, J., and Baltensperger, U.: New particle formation in the free troposphere: A question of chemistry and timing, Science, 352, 1109-1112, https://doi.org/10.1126/science.aad5456, 2016.

Boucher, O., Randall, D., Artaxo, P., Bretherton, C., Feingold, G., Forster, P., Kerminen, V.-M. V.-M., Kondo, Y., Liao, H., Lohmann, U., Rasch, P., Satheesh, S. K., Sherwood, S., Stevens, B., Zhang, X. Y., and Zhan, X. Y.: Clouds and Aerosols, in: Climate Change 2013: The Physical Science Basis. Contribution of Working Group I to the Fifth Assessment Report of the Intergovernmental Panel on Climate Change, Clim. Chang. 2013 Phys. Sci. Basis. Contrib. Work. Gr. I to Fifth Assess. Rep. Intergov. Panel Clim. Chang., 571-657, https://doi.org/10.1017/CBO9781107415324.016, 2013.

Crounse, J. D., Nielsen, L. B., Jørgensen, S., Kjaergaard, H. G., and Wennberg, P. O.: Autoxidation of organic compounds in the atmosphere, J. Phys. Chem. Lett., 4, 3513-3520, https://doi.org/10.1021/jz4019207, 2013.

Ditchfield, R.: Self-consistent molecular-orbital methods. IX. An extended gaussian-type basis for molecular-orbital studies of organic molecules, J. Chem. Phys., 54, 724-728, https://doi.org/10.1063/1.1674902, 1971.

Dunne, E. M., Gordon, H., Kürten, A., Almeida, J., Duplissy, J., Williamson, C., Ortega, I. K., Pringle, K. J., Adamov, A., Baltensperger, U., Barmet, P., Benduhn, F., Bianchi, F., Breitenlechner, M., Clarke, A., Curtius, J., Dommen, J., Donahue, N. M., Ehrhart, S., Flagan, R. C., Franchin, A., Guida, R., Hakala, J., Hansel, A., Heinritzi, M., Jokinen, T., Kangasluoma, J., Kirkby, J., Kulmala, M., Kupc, A., Lawler, M. J., Lehtipalo, K., Makhmutov, V., Mann, G., Mathot, S., Merikanto, J., Miettinen, P., Nenes, A., Onnela, A., Rap, A., Reddington, C. L. S., Riccobono, F., Richards, N. A. D., Rissanen, M. P., Rondo, L., Sarnela, N., Schobesberger, S., Sengupta, K., Simon,
M., Sipilä, M., Smith, J. N., Stozkhov, Y., Tomé, A., Tröstl, J., Wagner, P. E., Wimmer, D., Winkler, P. M., Worsnop, D. R., and Carslaw, K. S.: Global atmospheric particle formation from CERN CLOUD measurements, Science, 354, 1119-1124, https://doi.org/10.1126/science.aaf2649, 2016.

Duplissy, J., Merikanto, J., Franchin, A., Tsagkogeorgas, G., Kangasluoma, J., Wimmer, D., Vuollekoski, H., Schobesberger, S., Lehtipalo, K., Flagan, R. C., Brus, D., Donahue, N. M., Vehkamäki, H., Almeida, J., Amorim, A., Barmet, P., Bianchi, F., Breitenlechner, M., Dunne, E. M., Guida, R., Henschel, H., Junninen, H., Kirkby, J., Kürten, A., Kupc, A., Määttänen, A., Makhmutov, V., Mathot, S., Nieminen, T., Onnela, A., Praplan, A. P., Riccobono, F., Rondo, L., Steiner, G., Tomé, A., Walther, H., Baltensperger, U., Carslaw, K. S., Dommen, J., Hansel, A., Petäjä, T., Sipilä, M., Stratmann, F., Vrtala, A., Wagner, P. E., Worsnop, D. R., Curtius, J., and Kulmala, M.: Effect of ions on sulfuric acid-water binary particle formation: 2. Experimental data and comparison with QC-normalized classical nucleation theory, J. Geophys. Res.-Atmos., 121, 1-20, https://doi.org/10.1002/2015JD023538, 2016.

Ehn, M., Junninen, H., Petäjä, T., Kurtén, T., Kerminen, V.-M., Schobesberger, S., Manninen, H. E., Ortega, I. K., Vehkamäki, H., Kulmala, M., and Worsnop, D. R.: Composition and temporal behavior of ambient ions in the boreal forest, Atmos. Chem. Phys., 10, 8513-8530, https://doi.org/10.5194/acp-108513-2010, 2010.

Ehn, M., Junninen, H., Schobesberger, S., Manninen, H. E., Franchin, A., Sipilä, M., Petäjä, T., Kerminen, V.-M., Tammet, H., Mirme, A., Mirme, S., Hõrrak, U., Kulmala, M., and Worsnop, D. R.: An instrumental comparison of mobility and mass measurements of atmospheric small ions, Aerosol Sci. Tech., 45, 522-532, https://doi.org/10.1080/02786826.2010.547890, 2011.

Ehn, M., Thornton, J. a., Kleist, E., Sipilä, M., Junninen, H., Pullinen, I., Springer, M., Rubach, F., Tillmann, R., Lee, B., Lopez-Hilfiker, F., Andres, S., Acir, I.-H., Rissanen, M., Jokinen, T., Schobesberger, S., Kangasluoma, J., Kontkanen, J., Nieminen, T., Kurtén, T., Nielsen, L. B., Jørgensen, S., Kjaergaard, H. G., Canagaratna, M., Maso, M. D., Berndt, T., Petäjä, T., Wahner, A., Kerminen, V.-M., Kulmala, M., Worsnop, D. R., Wildt, J., and Mentel, T. F.: A large source of lowvolatility secondary organic aerosol, Nature, 506, 476-479, https://doi.org/10.1038/nature13032, 2014.

Franchin, A., Ehrhart, S., Leppä, J., Nieminen, T., Gagné, S., Schobesberger, S., Wimmer, D., Duplissy, J., Riccobono, F., Dunne, E. M., Rondo, L., Downard, A., Bianchi, F., Kupc, A., Tsagkogeorgas, G., Lehtipalo, K., Manninen, H. E., Almeida, J., Amorim, A., Wagner, P. E., Hansel, A., Kirkby, J., Kürrten, A., Donahue, N. M., Makhmutov, V., Mathot, S., Metzger, A., Petäjä, T., Schnitzhofer, R., Sipilä, M., Stozhkov, Y., Tomé, A., Kerminen, V. M., Carslaw, K., Curtius, J., Baltensperger, U., and Kulmala, M.: Experimental investigation of ion-ion recombination under atmospheric conditions, Atmos. Chem. Phys., 15, 72037216, https://doi.org/10.5194/acp-15-7203-2015, 2015.

Frisch, M. J., Trucks, G. W., Schlegel, H. B., Scuseria, G. E., Robb, M. A., Cheeseman, J. R., Scalmani, G., Barone, V., Mennucci, B., Petersson, G. A., Nakatsuji, H., Caricato, M., Li, X., Hratchian, H. P., Izmaylov, A. F., Bloino, J., Zheng, G., Sonnenberg, J. L., Hada, M., Ehara, M., Toyota, K., Fukuda, R., 
Hasegawa, J., Ishida, M., Nakajima, T., Honda, Y., Kitao, O., Nakai, H., Vreven, T., Montgomery Jr., J. A., Peralta, J. E., Ogliaro, F., Bearpark, M., Heyd, J. J., Brothers, E., Kudin, K. N., Staroverov, V. N., Kobayashi, R., Normand, J., Raghavachari, K., Rendell, A., Burant, J. C., Iyengar, S. S., Tomasi, J., Cossi, M., Rega, N., Millam, J. M., Klene, M., Knox, J. E., Cross, J. B., Bakken, V., Adamo, C., Jaramillo, J.,Gomperts, R., Stratmann, R. E., Yazyev, O., Austin, A. J., Cammi, R., Pomelli, C., Ochterski, J. W., Martin, R. L., Morokuma, K., Zakrzewski, V. G., Voth, G. A., Salvador, P., Dannenberg, J. J., Dapprich, S., Daniels, A. D., Farkas, O., Foresman, J. B., Ortiz, J. V.,Cioslowski, J., and Fox, D. J.: Gaussian 09, Revision B01, Gaussian, Inc., Wallingford CT, 2009.

Hirsikko, A., Nieminen, T., Gagné, S., Lehtipalo, K., Manninen, H. E., Ehn, M., Hõrrak, U., Kerminen, V.-M., Laakso, L., McMurry, P. H., Mirme, A., Mirme, S., Petäjä, T., Tammet, H., Vakkari, V., Vana, M., and Kulmala, M.: Atmospheric ions and nucleation: a review of observations, Atmos. Chem. Phys., 11, 767798, https://doi.org/10.5194/acp-11-767-2011, 2011.

Hoyle, C. R., Fuchs, C., Jarvinen, E., Saathoff, H., Dias, A., El Haddad, I., Gysel, M., Coburn, S. C., Trostl, J., Hansel, A., Bianchi, F., Breitenlechner, M., Corbin, J. C., Craven, J., Donahue, N. M., Duplissy, J., Ehrhart, S., Frege, C., Gordon, H., Hoppel, N., Heinritzi, M., Kristensen, T. B., Molteni, U., Nichman, L., Pinterich, T., Prevôt, A. S. H., Simon, M., Slowik, J. G., Steiner, G., Tome, A., Vogel, A. L., Volkamer, R., Wagner, A. C., Wagner, R., Wexler, A. S., Williamson, C., Winkler, P. M., Yan, C., Amorim, A., Dommen, J., Curtius, J., Gallagher, M. W., Flagan, R. C., Hansel, A., Kirkby, J., Kulmala, M., Mohler, O., Stratmann, F., Worsnop, D. R., and Baltensperger, U.: Aqueous phase oxidation of sulphur dioxide by ozone in cloud droplets, Atmos. Chem. Phys., 16, 1693-1712, https://doi.org/10.5194/acp16-1693-2016, 2016.

Hunter, E. P. and Lias, S. G.: Evaluate gas phase basicities and proton affinity of molecules: an update, J. Phys. Chem. Ref. Data, 27, 413-656, 1998.

Hyttinen, N., Kupiainen-Määttä, O., Rissanen, M. P., Muuronen, M., Ehn, M., and Kurtén, T.: Modeling the charging of highly oxidized cyclohexene ozonolysis products using nitratebased chemical ionization, J. Phys. Chem. A, 119, 6339-6345, https://doi.org/10.1021/acs.jpca.5b01818, 2015.

Kirkby, J., Curtius, J., Almeida, J., Dunne, E., Duplissy, J., Ehrhart, S., Franchin, A., Gagné, S., Ickes, L., Kürten, A., Kupc, A., Metzger, A., Riccobono, F., Rondo, L., Schobesberger, S., Tsagkogeorgas, G., Wimmer, D., Amorim, A., Bianchi, F., Breitenlechner, M., David, A., Dommen, J., Downard, A., Ehn, M., Flagan, R. C., Haider, S., Hansel, A., Hauser, D., Jud, W., Junninen, H., Kreissl, F., Kvashin, A., Laaksonen, A., Lehtipalo, K., Lima, J., Lovejoy, E. R., Makhmutov, V., Mathot, S., Mikkilä, J., Minginette, P., Mogo, S., Nieminen, T., Onnela, A., Pereira, P., Petäjä, T., Schnitzhofer, R., Seinfeld, J. H., Sipilä, M., Stozhkov, Y., Stratmann, F., Tomé, A., Vanhanen, J., Viisanen, Y., Vrtala, A., Wagner, P. E., Walther, H., Weingartner, E., Wex, H., Winkler, P. M., Carslaw, K. S., Worsnop, D. R., Baltensperger, U., and Kulmala, M.: Role of sulphuric acid, ammonia and galactic cosmic rays in atmospheric aerosol nucleation, Nature, 476, 429-433, https://doi.org/10.1038/nature10343, 2011.

Kirkby, J., Duplissy, J., Sengupta, K., Frege, C., Gordon, H., Williamson, C., Heinritzi, M., Simon, M., Yan, C., Almeida, J.,
Tröstl, J., Nieminen, T., Ortega, I. K., Wagner, R., Adamov, A., Amorim, A., Bernhammer, A.-K., Bianchi, F., Breitenlechner, M., Brilke, S., Chen, X., Craven, J., Dias, A., Ehrhart, S., Flagan, R. C., Franchin, A., Fuchs, C., Guida, R., Hakala, J., Hoyle, C. R., Jokinen, T., Junninen, H., Kangasluoma, J., Kim, J., Krapf, M., Kürten, A., Laaksonen, A., Lehtipalo, K., Makhmutov, V., Mathot, S., Molteni, U., Onnela, A., Peräkylä, O., Piel, F., Petäjä, T., Praplan, A. P., Pringle, K., Rap, A., Richards, N. A. D., Riipinen, I., Rissanen, M. P., Rondo, L., Sarnela, N., Schobesberger, S., Scott, C. E., Seinfeld, J. H., Sipilä, M., Steiner, G., Stozhkov, Y., Stratmann, F., Tomé, A., Virtanen, A., Vogel, A. L., Wagner, A. C., Wagner, P. E., Weingartner, E., Wimmer, D., Winkler, P. M., Ye, P., Zhang, X., Hansel, A., Dommen, J., Donahue, N. M., Worsnop, D. R., Baltensperger, U., Kulmala, M., Carslaw, K. S., and Curtius, J.: Ion-induced nucleation of pure biogenic particles, Nature, 533, 521-526, https://doi.org/10.1038/nature17953, 2016.

Kulmala, M., Vehkamäki, H., Petäjä, T., Dal Maso, M., Lauri, A., Kerminen, V. M., Birmili, W., and McMurry, P. H.: Formation and growth rates of ultrafine atmospheric particles: A review of observations, J. Aerosol Sci., 35, 143-176, https://doi.org/10.1016/j.jaerosci.2003.10.003, 2004.

Kulmala, M., Kontkanen, J., Junninen, H., Lehtipalo, K., Manninen, H. E., Nieminen, T., Petäjä, T., Sipilä, M., Schobesberger, S., Rantala, P., Franchin, A., Jokinen, T., Järvinen, E., Äijälä, M., Kangasluoma, J., Hakala, J., Aalto, P. P., Paasonen, P., Mikkilä, J., Vanhanen, J., Aalto, J., Hakola, H., Makkonen, U., Ruuskanen, T., Mauldin, R. L., Duplissy, J., Vehkamäki, H., Bäck, J., Kortelainen, A., Riipinen, I., Kurtén, T., Johnston, M. V, Smith, J. N., Ehn, M., Mentel, T. F., Lehtinen, K. E. J., Laaksonen, A., Kerminen, V.-M., and Worsnop, D. R.: Direct observations of atmospheric aerosol nucleation, Science, 339, 943-946, https://doi.org/10.1126/science.1227385, 2013.

Kürten, A., Bianchi, F., Almeida, J., Kupiainen-Määttä, O., Dunne, E. M., Duplissy, J., Williamson, C., Barmet, P., Breitenlechner, M., Dommen, J., Donahue, N. M., Flagan, R. C., Franchin, A., Gordon, H., Hakala, J., Hansel, A., Heinritzi, M., Ickes, L., Jokinen, T., Kangasluoma, J., Kim, J., Kirkby, J., Kupc, A., Lehtipalo, K., Leiminger, M., Makhmutov, V., Onnela, A., Ortega, I. K., Petäjä, T., Praplan, A. P., Riccobono, F., Rissanen, M. P., Rondo, L., Schnitzhofer, R., Schobesberger, S., Smith, J. N., Steiner, G., Stozkhov, Y., Tomé, A., Tröstl, J., Tsagkogeorgas, G., Wagner, P. E., Wimmer, D., Ye, P., Baltensperger, U., Carslaw, K. S., Kulmala, M., and Curtius, J.: Experimental particle formation rates spanning tropospheric sulfuric acid and ammonia abundances, ion production rates, and temperatures, J. Geophys. Res.-Atmos., 121, 12377-12400, https://doi.org/10.1002/2015JD023908, 2016.

Lehtipalo, K., Rondo, L., Kontkanen, J., Schobesberger, S., Jokinen, T., Sarnela, N., Kürten, A., Ehrhart, S., Franchin, A., Nieminen, T., Riccobono, F., Sipilä, M., Yli-Juuti, T., Duplissy, J., Adamov, A., Ahlm, L., Almeida, J., Amorim, A., Bianchi, F., Breitenlechner, M., Dommen, J., Downard, A. J., Dunne, E. M., Flagan, R. C., Guida, R., Hakala, J., Hansel, A., Jud, W., Kangasluoma, J., Kerminen, V.-M., Keskinen, H., Kim, J., Kirkby, J., Kupc, A., Kupiainen-Määttä, O., Laaksonen, A., Lawler, M. J., Leiminger, M., Mathot, S., Olenius, T., Ortega, I. K., Onnela, A., Petäjä, T., Praplan, A. P., Rissanen, M. P., Ruuskanen, T. M., Santos, F. D., Schallhart, S., Schnitzhofer, R., Simon, M., Smith, J. N., Tröstl, 
J., Tsagkogeorgas, G., Tomé, A., Vaattovaara, P., Vehkämäki, H., Vrtala, A. E., Wagner, P. E., Williamson, C., Wimmer, D., Winkler, P. M., Virtanen, A., Donahue, N. M., Carslaw, K. S., Baltensperger, U., Riipinen, I., Curtius, J., Worsnop, D. R., and Kulmala, M.: The effect of acid-base clustering and ions on the growth of atmospheric nano-particles, Nat. Commun., 7, 11594, https://doi.org/10.1038/ncomms11594, 2016.

Merikanto, J., Spracklen, D. V., Mann, G. W., Pickering, S. J., and Carslaw, K. S.: Impact of nucleation on global CCN, Atmos. Chem. Phys., 9, 8601-8616, https://doi.org/10.5194/acp-9-86012009, 2009.

Merikanto, J., Duplissy, J., Määttänen, A., Henschel, H., Donahue, N. M., Brus, D., Schobesberger, S., Kulmala, M., and Vehkamäki, H.: Effect of ions on sulfuric acidwater binary particle formation I: Theory for kinetic and nucleation-type particle formation and atmospheric implications, J. Geophys. Res.-Atmos., 121, 1736-1751, https://doi.org/10.1002/2015JD023538, 2016.

Metzger, A., Verheggen, B., Dommen, J., Duplissy, J., Prevot, A. S. H., Weingartner, E., Riipinen, I., Kulmala, M., Spracklen, D. V, Carslaw, K. S., and Baltensperger, U.: Evidence for the role of organics in aerosol particle formation under atmospheric conditions, P. Natl. Acad. Sci. USA, 107, 6646-6651, https://doi.org/10.1073/pnas.0911330107, 2010.

Nadykto, A. B.: Uptake of neutral polar vapor molecules by charged clusters/particles: Enhancement due to dipolecharge interaction, J. Geophys. Res.-Atmos., 108, 4717, https://doi.org/10.1029/2003JD003664, 2003.

Ortega, I. K., Kupiainen, O., Kurtén, T., Olenius, T., Wilkman, O., McGrath, M. J., Loukonen, V., and Vehkamäki, H.: From quantum chemical formation free energies to evaporation rates, Atmos. Chem. Phys., 12, 225-235, https://doi.org/10.5194/acp-12225-2012, 2012.

Praplan, A. P., Schobesberger, S., Bianchi, F., Rissanen, M. P., Ehn, M., Jokinen, T., Junninen, H., Adamov, A., Amorim, A., Dommen, J., Duplissy, J., Hakala, J., Hansel, A., Heinritzi, M., Kangasluoma, J., Kirkby, J., Krapf, M., Kürten, A., Lehtipalo, K., Riccobono, F., Rondo, L., Sarnela, N., Simon, M., Tomé, A., Tröstl, J., Winkler, P. M., Williamson, C., Ye, P., Curtius, J., Baltensperger, U., Donahue, N. M., Kulmala, M., and Worsnop, D. R.: Elemental composition and clustering behaviour of $\alpha$ pinene oxidation products for different oxidation conditions, Atmos. Chem. Phys., 15, 4145-4159, https://doi.org/10.5194/acp15-4145-2015, 2015.

Riccobono, F., Schobesberger, S., Scott, C. E., Dommen, J., Ortega, I. K., Rondo, L., Almeida, J., Amorim, A., Bianchi, F., Breitenlechner, M., David, A., Downard, A., Dunne, E. M., Duplissy, J., Ehrhart, S., Flagan, R. C., Franchin, A., Hansel, A., Junninen, H., Kajos, M., Keskinen, H., Kupc, A., Kürten, A., Kvashin, A. N., Laaksonen, A., Lehtipalo, K., Makhmutov, V., Mathot, S., Nieminen, T., Onnela, A., Petäjä, T., Praplan, A. P., Santos, F. D., Schallhart, S., Seinfeld, J. H., Sipilä, M., Spracklen, D. V., Stozhkov, Y., Stratmann, F., Tomé, A., Tsagkogeorgas, G., Vaattovaara, P., Viisanen, Y., Vrtala, A., Wagner, P. E., Donahue, N. M., Kirkby, J., Kulmala, M., Worsnop, D. R., and Baltensperger, U.: Oxidation products of biogenic emissions contribute to nucleation of atmospheric particles, Science, 344, 717-721, 2014.

Rissanen, M. P., Kurtén, T., Sipilä, M., Thornton, J. A., Kausiala, O., Garmash, O., Kjaergaard, H. G., Petäjä, T., Worsnop,
D. R., Ehn, M., and Kulmala, M.: Effects of chemical complexity on the autoxidation mechanisms of endocyclic alkene ozonolysis products: From methylcyclohexenes toward understanding $\alpha$-pinene, J. Phys. Chem. A, 119, 4633-4650, https://doi.org/10.1021/jp510966g, 2015.

Schobesberger, S., Junninen, H., Bianchi, F., Lönn, G., Ehn, M., Lehtipalo, K., Dommen, J., Ehrhart, S., Ortega, I. K., Franchin, A., Nieminen, T., Riccobono, F., Hutterli, M., Duplissy, J., Almeida, J., Amorim, A., Breitenlechner, M., Downard, A. J., Dunne, E. M., Flagan, R. C., Kajos, M., Keskinen, H., Kirkby, J., Kupc, A., Kürten, A., Kurtén, T., Laaksonen, A., Mathot S., Onnela, A., Praplan, A. P., Rondo, L., Santos, F. D., Schallhart, S., Schnitzhofer, R., Sipilä, M., Tomé, A., Tsagkogeorgas, G., Vehkamäki, H., Wimmer, D., Baltensperger, U., Carslaw, K. S., Curtius, J., Hansel, A., Petäjä, T., Kulmala, M., Donahue, N. M., and Worsnop, D. R.: Molecular understanding of atmospheric particle formation from sulfuric acid and large oxidized organic molecules, P. Natl. Acad. Sci. USA, 110, 17223-17228, https://doi.org/10.1073/pnas.1306973110, 2013.

Shuman, N. S., Hunton, D. E., and Viggiano, A. A.: Ambient and modified atmospheric ion chemistry: from top to bottom, Chem Rev., 115, 4542-4570, https://doi.org/10.1021/cr5003479, 2015.

Steiner, G., Jokinen, T., Junninen, H., Sipilä, M., Petäjä, T., Worsnop, D., Reischl, G. P., and Kulmala, M.: High-resolution mobility and mass spectrometry of negative ions produced in a 241 Am aerosol charger, Aerosol Sci. Technol., 48, 261-270, https://doi.org/10.1080/02786826.2013.870327, 2014.

Suni, T., Kulmala, M., Hirsikko, A., Bergman, T., Laakso, L., Aalto, P. P., Leuning, R., Cleugh, H., Zegelin, S., Hughes, D., van Gorsel, E., Kitchen, M., Vana, M., Hõrrak, U., Mirme, S., Mirme, A., Sevanto, S., Twining, J., and Tadros, C.: Formation and characteristics of ions and charged aerosol particles in a native Australian Eucalypt forest, Atmos. Chem. Phys., 8, 129-139, https://doi.org/10.5194/acp-8-129-2008, 2008.

Tröstl, J., Chuang, W. K., Gordon, H., Heinritzi, M., Yan, C., Molteni, U., Ahlm, L., Frege, C., Bianchi, F., Wagner, R., Simon, M., Lehtipalo, K., Williamson, C., Craven, J. S., Duplissy, J., Adamov, A., Almeida, J., Bernhammer, A.-K., Breitenlechner, M., Brilke, S., Dias, A., Ehrhart, S., Flagan, R C., Franchin, A., Fuchs, C., Guida, R., Gysel, M., Hansel, A., Hoyle, C. R., Jokinen, T., Junninen, H., Kangasluoma, J., Keskinen, H., Kim, J., Krapf, M., Kürten, A., Laaksonen, A., Lawler, M. J., Leiminger, M., Mathot, S., Möhler, O., Nieminen, T., Onnela, A., Petäjä, T., Piel, F., Miettinen, P., Rissanen, M. P., Rondo, L., Sarnela, N., Schobesberger, S., Sengupta, K., Sipilä, M., Smith, J. N., Steiner, G., Tomé, A., Virtanen, A., Wagner, A. C., Weingartner, E., Wimmer, D., Winkler, P. M., Ye, P., Carslaw, K. S., Curtius, J., Dommen, J., Kirkby, J., Kulmala, M., Riipinen, I., Worsnop, D. R., Donahue, N. M., and Baltensperger, U.: The role of low-volatility organic compounds for initial particle growth in the atmosphere, Nature, 533, 527-531, https://doi.org/10.1038/nature18271, 2016.

Zhao, Y. and Truhlar, D. G.: The M06 suite of density functionals for main group thermochemistry, thermochemical kinetics, noncovalent interactions, excited states, and transition elements: Two new functionals and systematic testing of four M06-class functionals and 12 other function, Theor. Chem. Acc., 120, 215-241, https://doi.org/10.1007/s00214-007-0310-x, 2008. 